\title{
EMILY UMBERGER
}

ARIZONA STATE UNIVERSITY

\section{Bac on the Border}

For Larry Fane

I

NCREASED ATTENTION IN RECENT decades on the late eighteenth-century Franciscan mission church of San Xavier del Bac near present-day Tucson, ${ }^{\mathrm{I}}$ Arizona, invites further study of many features of the structure (fig. I). The great number and arrangement of its paintings and sculptures (fig. 2) indicate that its creators, friars Velderrain and Llorens, had ambitions for this church

I. See especially the work of Bernard L. Fontana, Biography of a Desert Church: The Story of Mission San Xavier del Bac, The Smoke Signal 3, originally published in 1961, reissued in revised form in 1996, Tucson, Tucson Corral of Westerners; and "Who Were the Decorators and Builders of Mission San Xavier del Bac?”, The Kiva, Tucson, Arizona Archaeological and Historical Society, 6r:4 (1996), pp. 365-384. Another classic is Richard E. Ahlborn's study of the sculptures, The Sculpted Saints of a Borderland Mission: Los Bultos de San Xavier del Bac, Tucson, Southwestern Mission Research Center, 1974. For paintings in the church, see Robert Olney, An Analysis of the Murals and Figural Arrangements of San Xavier del Bac Mission, MA thesis, Tempe, Arizona State University, 1996. A new book by Ahlborn and Yvonne Lange adds further information on the iconography of both sculpted and painted images, Lange and Ahlborn, Mission San Xavier del Bac: A Guide to Its Iconography, Tucson, University of Arizona Press, 2004.

Fontana's 915-page annotated bibliography on the Papagos, the Pimería Alta, and the mission, begun in 1956, has been posted as a website by the Tumacácori National Historical Park www.nps. gov/tuma/. For a panorama of the entire interior, see University of Arizona Virtual Reality Annex, Office of Student Computing Resources, no date, http://qtvr.Arizona.edu/hi_res.html (called to my attention by Gretchen Gibbs). Also see the church's website: Brother Bryan Trawick, ofM, San Xavier del Bac Mission, Official Website, no date, www.sanxaviermission.org, which includes the transcript of a television documentary, KUAT-TV, "Divine Mission: San Xavier del Bac", narrated by Linda Ronstadt, 1997. The videotape itself can be ordered at www.kuat.org/sx/sx.html. 
beyond others in the Arizona-Sonora chain. They were evidently inspired by structures further south for its forms and layout. In addition, they imported most of Bac's artworks and brought some artists to the church from the metropolitan centers of New Spain (now Mexico). ${ }^{2}$

There are many factors to consider in the scholarly analysis of the church. Its original environment was very different from the present one. Although now on a reservation in the modern US Southwest, the church was built on the northern frontier of a Spanish viceroyalty by Franciscans at a mission site that had been founded by the Jesuit order a century earlier. There were two very different audiences from the outset and both changed greatly over time: the Franciscans and other observers who arranged and read its artworks in Euro-Christian ways; and the Native Americans, the recipients of teaching through these same images, who might have read them differently. The published information on the church comes from the former, not the latter.

My focus is the Franciscan program during the church's Hispanic period, an eclectic mix of sculptures in different materials, techniques, and styles, linked by painted decorations. Blanks in our knowledge about its design introduce complex problems, which, although probably without definitive solutions, can be tackled. Many local studies of the corpus have been accomplished and the materials have been published or are in the process of being made available to researchers (see n. I). These include archaeological reports, documents and photographs, studies of materials and manufacturing techniques, and observations of usage. On the basis of these resources, it is possible to use art historical methods to place the church within the broader context of the world of Spanish and New Spanish religious art. Even if the artists cannot be identified by name, their numbers and levels of skill may be hypothesized through study of the images themselves, and their places of

2. As the result of recent studies at the church, Fontana ("Who Were the Decorators?", I996, p. 37I) was able to state definitively that all the wooden sculpture parts were imported, as were other rare materials used in the church decoration. For the importation of objects to New Mexico, see Marc Simmons, "Colonial New Mexico and Mexico: The Historical Relationship", in Colonial Frontiers, Art \& Life in Spanish New Mexico, Christine Mather (ed.), Santa Fe, Ancient City Press (The Fred Harvey Collection), I983, pp. 7I-89; for California, see Martin J. Morgado, Junipero Serra's Legacy, Pacific Grove, California, Mount Carmel, 1987. On the acquisition by other missions of northwest New Spain of imported artworks and materials from central Mexico, see Clara Bargellini, "At the Center on the Frontier: The Jesuit Tarahumara Missions of New Spain", paper delivered at the International Congress of the History of Art, London, 2000, revised MS of 2004. The activities of trained artists in the Southwest us have not been studied. 


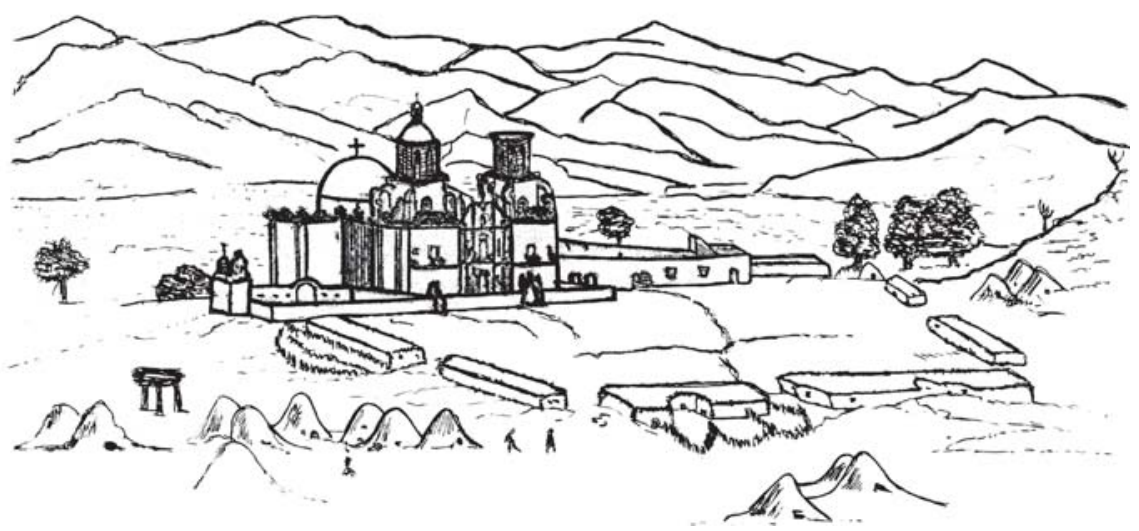

I. H. M. T. Powell, drawing of the Franciscan mission church of San Xavier del Bac, south of Tucson Arizona, at the end of Spanish/Mexican period, October 9, I 849; original location of his sketchbook unknown (drawing after one published in Over the Santa Fé Trail to California: The Journal and Drawings of H. M. T. Powell, I849-1852, edited by Douglas S. Watson, The Book Club of California and E. \& R. Grabhorn, San Francisco, I 93 I, opposite page I44).

training and later activities may be discovered from comparison with productions in particular areas of Mexico.

That the church's iconographic program was designed in tandem with the new structure is indicated by the first description of the church in the year of its inauguration, 1797. Mentioned are paintings on the walls, dome, and choir loft and thirty-two sculptures, meaning most of those now there. ${ }^{3}$ The program focused on two sculptures that were moved from the earlier Jesuit structure at the site. These were joined by the majority of the remaining sculptures, whose style indicates that they must have been sent together as a commission from a single workshop or a group of connected workshops, presumably before the consecration of the church. Others may have arrived later from the same or different sources. With the addition of two final figures representing the parents of Christ sometime after I 848 , the present ensemble appears to have been in place. These last figures were probably replacements for images of the same personages in the original program. Although the major sculptures that were focal points

3. Father Francisco Iturralde's 1797 description, "Visita de las Misiones de la Pimería por el P. Iturralde, Presid.te. Tubutama”, original Ms in the Franciscan General Archives in Rome; English translation by Father Luis Baldonado, published in Fontana, Biography of a Desert Church, p. 24. 
in the layout of 1797 have remained in the same places, anomalies in the locations of some of the small sculptures in peripheral niches indicate that changes were made after that date. Principally, the addition or enlargement of the pulpit seems to have led to their rearrangement, and this happened probably sometime between the I 85 os, when the church became a us possession, and the I 870 , when the first photographs of its interior were taken. After this, the Anglo period seems to have been characterized by only minor adjustments and repairs at the church, as it became increasingly a site of historical veneration and tourism.

In this essay, I will highlight the following topics: the relationship of the existing Franciscan program to the Jesuit program that preceded it, the sources and original arrangement of figures, style linkages among the large group of portable sculptures and what they imply about the hypothetical workshop/s, the artist/s who worked at the church itself, and the possibility of a different reading of the program by native audiences.

From the outset the Franciscan structure at Bac stood out from other northern New Spanish missions in its elaborate decoration, and it still stands out, because its contents were never destroyed or dispersed. The church's roof did not collapse, it was not seriously damaged by natural disasters, and members of the native congregations guarded its art during times of abandonment by religious. In addition, the international border that separated Bac from most of the other churches in the Arizona-Sonora mission chain protected it from Mexican post-Revolutionary activists who destroyed religious imagery in the 193 os. ${ }^{4}$ The result is that $\mathrm{Bac}$ has the most elaborate missionary program from its time on the northern frontier of the viceroyalty. In addition to documenting eighteenth-century Franciscan ideas, it provides evidence seemingly not available elsewhere about the transferal of Jesuit properties and ideas after the order's expulsion from Spanish territories in $1767 . .^{5}$

4. During the decades after the Mexican Revolution, images of saints were destroyed in different areas of that country. On Sonora, see James S. Griffith, Beliefs and Holy Places: A Spiritual Geography of the Pimeria Alta, Tucson/London, University of Arizona Press, 1992, 5off; and Adrian A. Bantjes, As If Jesus Walked on Earth: Cardenismo, Sonora, and the Mexican Revolution, Wilmington, Delaware, Scholarly Resources, 1998. See also La arqueología del régimen 1910-1955, Mexico City, Museo Nacional de Arte, 2003, pp. 39-4I. Tumacácori was likewise spared of this type of political attack, but its interior and images suffered other damage.

5. See also Barbara C. Anderson on the reuse of Jesuit sculptures by other groups. She suggests that after the expulsion Jesuit church images were handled rather cavalierly by the remaining religious ("The Expulsion of the Jesuits and the Decline of Religious Iconography in Eighteenth 


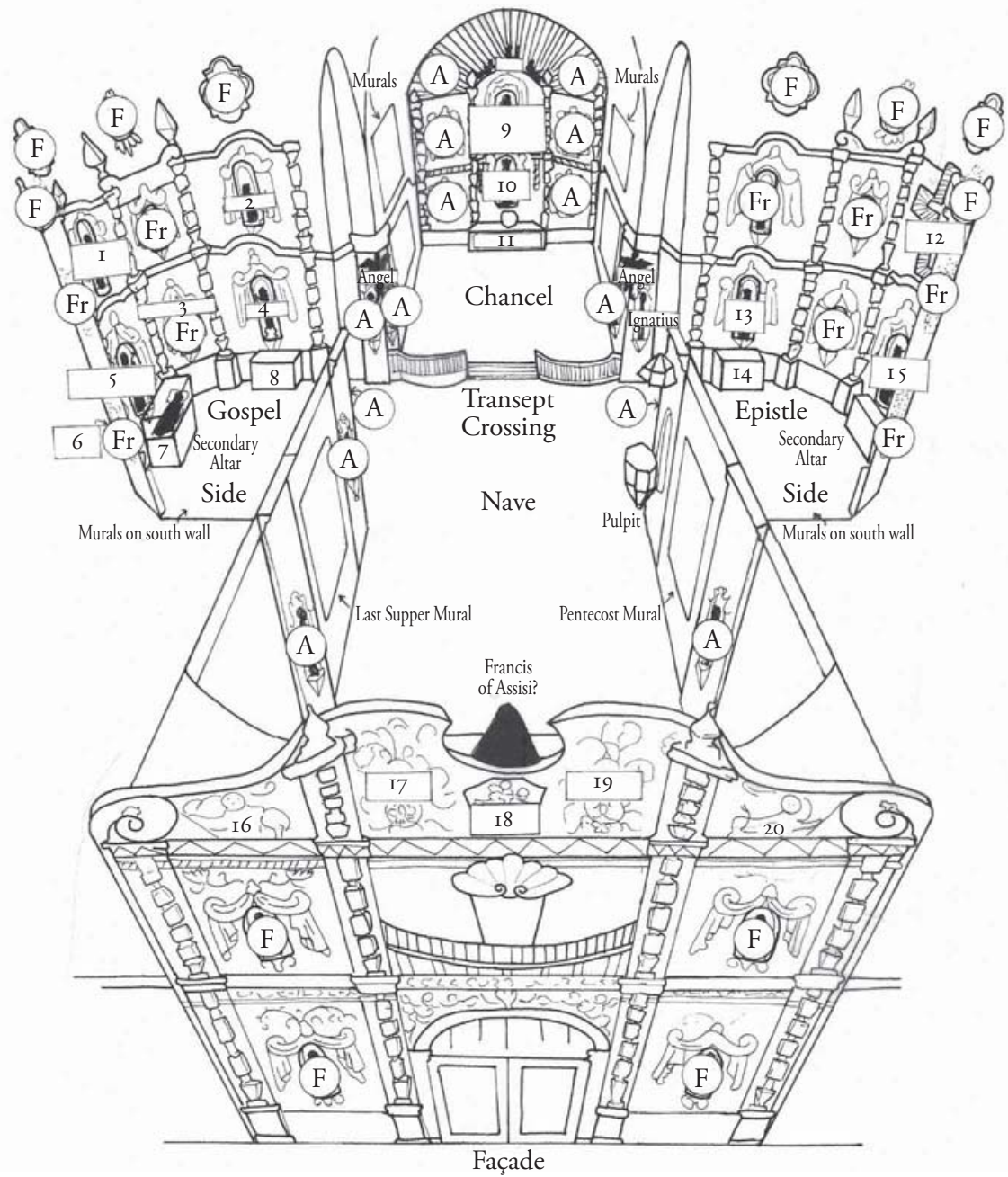

2. Diagram of figural sculptures as presently arranged in the church at Bac (redrawn and relabeled by the author after Richard Ahlborn, The Sculpted Saints of a Borderland Mission: Los Bultos de San Xavier del Bac, Tucson, Southwestern Mission Research Center, I974, p. 35). Key: $\mathrm{F}=$ Female, $A=$ Apostle, $\mathrm{Fr}=$ Small Franciscan, $\mathrm{M}=$ Male martyr. I. Francis of Assis; 2. Dominic; 3. Bonaventure; 4. Joseph; 5. Christ as Man of Sorrows; 6. Duns Scotus?; 7. Fx Bier; 8. Tertiary Altar; 9. Virgin of the Immaculate Conception; Io. Francis Xavier; I I. Main Altar; I 2. Crucified Christ; I3. Virgin Mary; I4. Tertiary Altar; I 5. Virgin of Sorrows; I6. Lion; 17. Monogram of Christ; I8. Franciscan Escudo; 19. Monogram of the Virgin; 20. Lion. 
DOI: http://dx.doi.org/10.22201/iie.18703062e.2007.91.2250

74

EMILY UMBERGER

\section{The Jesuit Mission at Bac}

Long before the creation of the Franciscan church, Eusebio Francisco Kino (I645-I7II) entered the area now covered by northern Sonora and southern Arizona. The year was I687, near the end of the Habsburg era in Spain, and the region was called the Pimería Alta after its Native American inhabitants, who were then as now categorized broadly as speakers of Piman languages. After establishing his headquarters at Dolores, the village of Cosari in Sonora, Kino went to Bac in $\mathrm{I} 692$ and designated it as the site of missionary activities addressed to a local Papago group, the Sobaípuris who inhabited the rancheria (village) there. In later years other Papagos joined the Sobaípuris. Today the Sobaípuris are extinct, and the inhabitants of the San Xavier Reservation, created around the church in 1874 , are descendants of these other, late arriving Papagos. They call themselves Tohono O'odom ("Desert People"), O'odom being a generic name used by Piman groups.

We know little of Jesuit conversion techniques at this site, ${ }^{6}$ and little of how the native congregations received the Jesuit ministry. No sermons are known,

Century Mexico", New Mexico Studies in the Fine Arts, Albuquerque, University of New Mexico, I (1976), pp. 37-39).

6. For the Jesuits in New Spain, see Gerard Decorme, La obra de los jesuitas mexicanos durante la época colonial, I572-I767 (compendio histórico), 2 vols., Mexico City, Antigua Librería Robredo de J. Porrúa e Hijos, I94I; and Francisco J. Alegre, Historia de la Provincia de la Compañia de Jesús de Nueva España, Ernest J. Burrus and Félix Zubillaga (eds.), 4 vols., Institutum Historicum, Rome, 1956-1960. For generalities of Jesuit conversion in Northwestern Mexico, see Charles W. Polzer, Rules and Precepts of the Jesuit Missions of Northwestern New Spain, Tucson, University of Arizona Press, 1976; and Andrés Pérez de Ribas, History of the Triumphs of Our Holy Faith amongst the most Barbarous and Fierce Peoples of the New World, Daniel T. Reff et al. (trans.), with annotation and critical introduction by Daniel T. Reff, Tucson, University of Arizona Press, 1999 (in Spanish, Historia de los triumphos..., [Madrid, I645] Mexico City, Layac, 1944).

On Kino, see Herbert Eugene Bolton, Kino's Historical Memoir of Pimería Alta, I542-I7II, Cleveland, I919, 2 vols., and Rim of Christendom, New York, Macmillan, 1936; Ernest J. Burrus, Kino and Manje, Explorers of Sonora and Arizona, Their Vision of the Future, A study of their Expeditions and Plans, Rome, Jesuit Historical Institute, and St. Louis, Missouri, St. Louis University, I97I; and Charles W. Polzer, Kino, A Legacy. His Life, His Works, His Missions, His Monuments, Tucson, Jesuit Fathers of Southern Arizona, 1998 (a revision of his Kino Guide II, Tucson, Southwestern Mission Research Center, 1982, which in turn was a revision of a publication of 1968).

For an overview history of the Southwest us after Spanish contact, see Edward H. Spicer, Cycles of Conquest: The Impact of Spain, Mexico and the United States on the Indians of the Southwest, 1533-1960, Tucson, University of Arizona Press, 1962. 
and there are few material remains and documents. Until 1756 the Jesuits had only modest buildings, a "house" for a friar and an open ramada serving as a church. Nevertheless, we know that Kino himself had ambitions for Bac. Having named it after his patron saint, Francis Xavier, he envisioned it as the site of a head church for missions yet to be founded in the territories he was exploring further north and west. He never completed a significant ecclesiastical structure at Bac; nor was any mission founded in the areas further north. If his dream had been accomplished, however, Bac might have replaced his headquarters at Dolores. ${ }^{7}$

It was Alonso Espinosa who built the first true church in 1756, forty-five years after Kino's death. According to hypotheses made from archaeology at the site, this structure was a rectangular hall church, oriented with the chancel to the north and the entrance to the south. It had thick walls of sun-dried adobes and a flat roof made of wooden beams covered by earth. The appearance of the exterior is unknown, but an inventory written in 1768 mentions important aspects of the interior, notably three altar tables. ${ }^{8}$ The principal altar was devoted to Francis Xavier, the dedicatory saint; on it was featured his sculpted image dressed in real clothing. According to a document discovered by J. Augustine Donohue, Espinosa ordered it from Mexico City in I759: "a head and hands of San Xavier with a body frame resembling the statue in Vera Cruz."9 It is assumed by modern scholars that the dedicatory figure of the

7. Polzer implies this (Kino, A Legacy, pp. 68-70). See also J. Augustine Donohue, "The Unlucky Jesuit Mission of Bac, 1732-1767", Arizona and the West, Tucson, University of Arizona Press, 2:2 (1960), pp. I27-I28.

8. The inventory, drawn up by the Civil Commissioner Andrés Grijalva, is in the "Inventarios de lo que se entregó a los Ministros de Sonora, año de 1768", Archivo del Colegio de la Santa Cruz de Querétaro, K. núm. 8, leg. I4. Jorge Olvera's English translation is in Fontana, Biography of a Desert Church, pp. I6-I8.

For written and archaeological evidence of the Jesuit buildings at Bac and their contents, see Fontana, Biography of a Desert Church, pp. 5-7, I3-I 4, I6-19, and 33. On Jesuit churches in Sonora, see Mardith Schuetz-Miller and Bernard L. Fontana, "Mission Churches of Northern Sonora", in The Pimería Alta: Missions \& More, James E. Officer et al. (eds.), Tucson, Southwestern Mission Research Center, 1966, pp. 6I-65. The drawing on page 6I resembles the Bac church as described by Fontana. See also, Paul M. Roca, Paths of the Padres through Sonora: An Illustrated History \& Guide to Its Spanish Churches, Tucson, Arizona Pioneers' Historical Society, 1967.

9. Donohue, "Unlucky Jesuit Mission", p. I37; his source is in the Archivo Histórico de Hacienda, Mexico City, Temporalidades, leg. 323, exp. 3. Clara Bargellini, personal communication, suggests that the reference is to the image (now lost) in the chapel dedicated to the saint in the church of the Veracruz in Mexico City. 
Franciscan church is the one listed in the inventory, ${ }^{10}$ given its closeness to the description (fig. 3). ${ }^{\text {I }}$

Other features of the main altar were a gilded wood tabernacle, paintings of Saint Joseph and the Virgin Mary in gilded frames, a small painting of the dedicatory saint, and four engravings on paper, whose subjects and framing are not mentioned. A 1763 document, also found by Donohue, gives further details about the two framed paintings: they were $\mathrm{I}-3 / 4$ varas (about five feet) in height, represented Saint Joseph and Our Lady of Refuge (a specific Marian type), and were "by the hand of Cubrera." ${ }^{22}$ Richard Ahlborn guesses that the reference is to Miguel Cabrera, the great painter active in Mexico City in the mid-eighteenth century. ${ }^{\mathrm{I}}$ The paintings were probably by a follower. Given their size and subjects, they must have been half-length figures rather than heads or full-length figures. ${ }^{14}$ Nothing in the inventory or any other description indicates the presence of an altarpiece behind the altar. The mention of frames for these two paintings suggests, rather, that they were hung on the walls.

Of the two secondary altars peripheral to the main altar, one was devoted to the Virgin of Sorrows, the Dolores after whom Kino named his head town in Sonora. On this altar was another sculpture dressed in real clothing, imported from an unnamed location. The document of 1763 indicates its presence in the church by that time, and gives details on the form of the figure ("una cabeza, $y$ manos de Nra Sra de los Dolores/ con la demas armazon para el cuerpo"). The description matches the present figure, which has removable hands, a dressed torso, and an armature for the lower body, like the Saint Francis Xavier figure. It is currently the focus of the Eastern/Epistle transept arm of the Franciscan church and the dedicatory figure of the altar at its end (fig. 4). ${ }^{15}$ Mentioned in both the 1763 and 1768 documents are the Virgin's appurtenances and articles of jewelry, mostly of silver, which recall similar objects in the wardrobes pertaining to Her in other Hispanic churches. The present sculpture still wears

Io. Fontana, Biography of a Desert Church, p. I6.

I I. See photos and details of construction in Ahlborn, Sculpted Saints, cover and pp. 92-93.

I2. Archivo Histórico de Hacienda, Mexico City, leg. 321, exp. 27, microfilm copy in Bancroft Library, Berkeley, California, University of California (Ahlborn, Sculpted Saints, p. I20, n. 33). Thanks to David Kessler of the Bancroft Library for finding the microfilm of this document (February, 2005).

I3. Alhborn, ibidem, p. I20.

I4. Clara Bargellini, personal communication.

15. Ahlborn, Sculpted Saints, p. I5. 
3. Dedicatory sculpture of Saint Francis

Xavier, a wooden processional sculpture, dressed in real clothing. The body was carved and painted in Mexico in about 1759 for the Jesuit church at Bac. It was later transferred to the Franciscan church.

Photograph by the author 2005 .

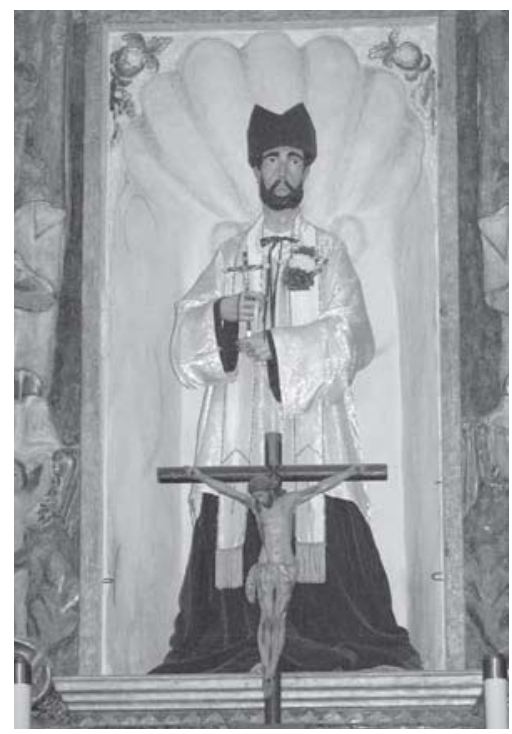

the silver halo-crown mentioned, and a slit in the chest indicates that a dagger, also listed but now gone, was once implanted there to symbolize the Virgin's pain. ${ }^{16}$ Whether her altar was on the west side of the main altar or on the east, as it is now, is not indicated by any document, but a location comparable to its present one would be logical. ${ }^{17}$

The 1768 inventory gives some information about the third altar in the Jesuit church. Associated with it were four prints on paper, a green curtain, and six metal wall candlesticks, but the subjects of the prints are not mentioned; nor is a sculpture. Given that the other two altars had major figures on them, the lack of a sculpture is surprising. Was Espinosa unable to obtain the image needed to complete the program? Or did someone take a sculpture from the church before the Franciscan arrival? In the present, Franciscan church, the niche directly above the altar is occupied by an image of Christ as Man of Sorrows, while an image that represents Saint Francis Xavier lies

16. Ahlborn mentions the slit in the torso and illustrates the sculpture (Ahlborn, ibidem, p. I04). For a similar sculpture of the Virgin of Sorrows with a silver halo and dagger, which has been attributed to the Spaniard Pedro de Mena, see Clara Bargellini's book on the retable from the chapel at the Jesuit Hacienda of Santa Lucía (El Retablo de la Virgen de los Dolores, Mexico City, Fundación Cultural Televisa-Centro Cultural Arte Contemporáneo, 1993).

17. Ahlborn, Sculpted Saints, pp. I5-I6. 
in a glass coffin or bier on the altar, incorrupt as his body was said to be in Goa, India. The Xavier sculpture is actually a reused processional Christ figure of unknown origin and date of arrival at Bac. ${ }^{18}$ It now represents the Jesuit dedicatory saint, but it is not mentioned in the Jesuit inventory, and it was probably not in the Jesuit church. As will be argued later on the basis of style, the standing Christ sculpture was made for the new Franciscan church, but it is most likely that a comparable sculpture of Christ at the time of the Passion existed or was anticipated in the earlier structure, to balance the Virgin of Sorrows. ${ }^{19}$ Given the north-south orientation of the church, the west side would have been on the proper right-hand of the main altar, the Gospel Side, from the point of view of God at the top of the main altarpiece or a cleric facing the congregation, and the east side would have been on the proper left-hand, the Epistle Side. According to Christian ideas, the Gospel Side had priority in multiple senses over the Epistle Side. ${ }^{20}$ If the Virgin of Sorrows were on the east side and a male figure were on the west, this would correspond with the rules of priority in terms of gender and time.

I8. Ibidem, pp. 78-79. Processional figures of Christ usually have movable joints, as this one does, so they can be posed in different ways during Holy Week. A body in a coffin is first mentioned as being seen at Bac in 1849 (ibidem, p. I6). Whether the I849 figure is the present one is unknown, nor whether it was meant to be Christ or Francis Xavier. Francis Xavier's body is replicated in another recumbent figure sculpture further south in Magdalena, Sonora. This second one clearly represents a personage in a monastic costume (in other words, it is not a Christ figure). The modern sculpture now in Magdalena replaced an earlier one destroyed in the I930s. Both the Magdalena and Bac sculptures are objects of pilgrimage (Griffith, Beliefs and Holy Places, chapter 3).

I9. This was customary in Mexico (Clara Bargellini, La Catedral de Saltillo y sus imágenes, Mexico City, Universidad Nacional Aútonoma de México-Instituto de Investigaciones Estéticas/Gobierno del Estado de Coahuila-Instituto Coahuilense de Pintura, 2005, p. 32). See also Clara Bargellini ("Jesuit Devotions and Retablos in New Spain", in The Jesuits: Cultures, Sciences, and the Arts, I540-1773, John W. O’Malley et al. (eds.), Toronto/Buffalo/London, University of Toronto Press, 1999, pp. 687-692) on the Jesuit promotion of the Virgin of Sorrows in New Spain and on some iconographic arrangements involving this Marian type in Mexican churches.

The present, standing Christ at Bac could not be an Ecce Homo (the presentation of Christ to the crowd), given the position of the raised, unmovable arms. As Ahlborn noted (Sculpted Saints, p. 76), it was intended to carry a cross and is thus Christ on the way to Calvary, a later time during Christ's final week.

20. Barbara C. Anderson, The Figural Arrangements of Eighteenth-Century Churches in Mexico, Ph.D. Dissertation, Yale University, I979, pp. 37, 39, 85, I02, I64, 213, and elsewhere (Ann Arbor, Michigan, University Microfilms International, 1980). 
4. Sculpture of the Virgin of Sorrows, wooden processional sculpture dressed in real clothing; body carved and painted in Mexico before 1763 . It was first located in the Jesuit church at Bac and then transferred to the Franciscan church, where it is on the secondary Epistle Side altar. The Virgin wears her original silver crown and halo, but lacks the silver dagger once in her breast. Photograph by the author 2005 .

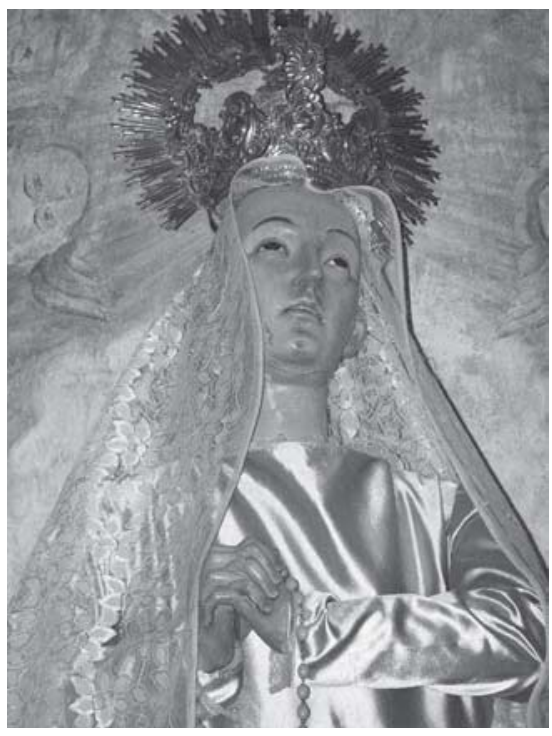

In I 767, only eleven years after the initiation of Espinosa's church, the Bourbon kings of Spain expelled the Jesuits from their territories all over the world, including the Arizona-Sonora mission chain, and the inventory, the church, and the church's contents were given to the Franciscan friar Francisco Hermenegildo Garcés who was sent to replace them there. ${ }^{21}$

\section{The Franciscan Elaboration of the Jesuit Program 22}

Garcés ministered to the residents of Bac until his departure in I779. He was replaced by Juan Bautista Velderrain, a friar who had been at the site since 1776

2I. For Franciscan ideas on conversion in northwestern Mexico, see Daniel S. Matson and Bernard L. Fontana (trans. and eds.), Father Bringas Reports to the King: Methods of Indoctrination on the Frontier of New Spain 1796-97, Tucson, University of Arizona Press, I977.

22. Lange and Ahlborn, Mission San Xavier, chapter 5, also suggest Jesuit retentions in the Franciscan church but their examples are based on the presence of imagery that they consider particularly Jesuit rather than the evidence of the inventories and of stylistic relationships among sculptures. And, in some cases, it is unclear whether they are referring to an idea or an actual object. See Pal Keleman ("The Significance of the Stone Retablo of Cristo Rey", El Palacio, 
and who began construction of the Franciscan church at some time between $\mathrm{I} 780$ and I783. The building itself was probably finished by I 788 . Velderrain died in 1790 , and was succeeded by Juan Bautista Llorens, a new arrival who directed the completion of the decoration. The church was inaugurated in 1797. The degree and nature of collaboration between Velderrain and Llorens is unknown. Franciscans who reported to administrators in Mexico to the south controlled the site until I 844, when they too left the area. ${ }^{23}$ Archaeology reveals that they buttressed the failing walls of the Jesuit structure, presumably while they were still using it as their primary church. Other evidences indicate that they disassembled this older building before I 843 and reused the materials to build the wing of the cloister that was seen then and still abuts the Franciscan church. ${ }^{24}$

The period during which the Jesuit church was the Franciscans' primary religious structure was approximately twenty to thirty years in length - depending on when between I 788 and I 797 they began using the new one-and a number of similarities between the two indicate purposeful continuity. Perhaps ambitions similar to those of Father Kino when he founded the first mission there - the anticipation that this would be a center for further foundations to the north - were behind the later Franciscan structure. Although the new church was in the form of a cross, with a transept containing the secondary altars at the ends, it preserved the north-south orientation of the Jesuit structure. Thus, the Gospel Side remained to the west of the main altar and the Epistle Side to the east. The Franciscans also kept the dedications of the main altar and one of the side altars (possibly both), and transferred the sculptures of Saint Francis Xavier and the Virgin of Sorrows to the new church.

It seems, in fact, that the Franciscans kept the essence of the Jesuit program and elaborated on it. In addition to moving the secondary altars into the transept arms, they added a pair of tertiary altars at the junctures of the transept with the main body of the church. These altars were conceived as parts of their respective transept arm ensembles and, simultaneously, as a pair flanking the

Santa Fe, Museum of New Mexico, 6r:8 (1954), pp. 243-263) for inclusion of Jesuit imagery in Franciscan New Mexico (for which he gives a political explanation).

23. After a period of total abandonment followed by a period when other Christian religious attempted to reestablish the mission and/or administer a school there, Franciscans of the us Catholic Church inherited the structures at Bac in I9I3. Members of the order now report to superiors in Oakland, California (Fontana, Biography of a Desert Church, pp. 37-52, passim).

24. Ibidem, pp. I4, 2I-24, $3 \mathrm{I}$. 
chancel with its main altar. The builders who worked for the Franciscans also pierced the walls above all altars with niches for full-length figures on two levels, framed the niches vertically with estipite columns, and topped them horizontally with cornices to create the effect of Baroque retablos (retables). The niches are of two sizes, a large size reserved for two levels of figures above each of the five altars, and a smaller size for flanking figures. To tie together the altars within the transepts, the retables behind them were extended to meet at bends in the walls. Above the cornices a third level of small niches was created for three-quarter-length figures in the case of the transepts and (decapitated) heads in the case of the main retable. A great fluted "shell" topped the main retable. Like the walls themselves, all cornices and estipites were made of bricks, which were shaped and then plastered and painted. Shaped and painted plaster swags, imitating patterned cloth, framed the niches. Plaster bases for candles were used instead of metal sconces on the walls. The ceilings of the nave, transept, and chancel were also sculpted and painted as shallow domes decorated with floral motifs or with faux folded cloth. The Franciscans also had figures in-the-round constructed of brick and plaster on the façade, above the retable cornices, and on walls and estipites in various places (e.g., angels of different ages). To fill the large niches they used the sculptures acquired from other churches or ordered from further south. Some of these were already dressed in garments made of wood or stiffened cloth, but most consisted of wooden bodies (like manikins), which were dressed in real clothing or plaster garments once they were at Bac. ${ }^{25}$

All parts of the church were covered with paintings. On the walls framed narrative and figural scenes participated in the iconographic program. The great dome over the crossing was decorated with painted images of saints and holy figures. Large and small flowers are among the textile patterns found in the clothing of two-dimensional figures and the swags over niches, as well as the clothed sculptures. Also noteworthy are elaborate interlaces, geometric hatching and net-like patterns, as well as the painted faces and bodies of attached sculptures. Gilding was applied to the estipites of the main retable and glazes were painted on silver surfaces flanking these supports. ${ }^{26}$ Imitating other objects and materials that were not attainable at Bac are a dado of faux tiles, faux marbling, and faux wooden doors, seat backs, and picture frames.

25. On the techniques of construction, see Ahlborn (Sculptured Saints).

26. For the results of recent materials studies, see Fontana ("Who Were the Decorators?"). 
The interrelationships among these varied forms at the church need further study to indicate which paintings were integral to the installation of the I790s and which not, and to determine the order of their placement and execution. Whatever the results, it is evident that the general plan of the iconographic program dates from that time, and the identities of the majority of sculpted and painted images were anticipated in the original plan, even if the actual objects were not present.

Primary among the Franciscans' physical retentions from the old church were the sculptures of Saint Francis Xavier and the Virgin of Sorrows. Both are processional figures and the present congregation uses them this way, removing them from their niches for rituals in other parts of the church or outside. ${ }^{27}$ One must conclude that they were part of the native Christianity introduced by the Jesuits after their arrival at Espinosa's church, and were retained for this reason as well as for their value as finely made sculptures. ${ }^{28}$

In addition to moving sculptures and paraphernalia from the Jesuit church into the new structure, the Franciscans replaced other art forms with their own versions. The most obvious of the replaced objects is the tabernacle (cupboard for the sacramental wine and bread) directly above the main altar. Being stylistically related to the other forms in the new church, it is easily recognizable as a replacement. The images of Joseph and Mary, the dedicatory saints of the tertiary altars on either side of the chancel, were replacements for the paintings of these two near the Jesuit main altar, but the history of these replacements is more complex. The 1797 description of the Franciscan church indicates that the tertiary altars intended for them were integral to the new ensemble, but if there were images on the altars, they are not mentioned. I do not doubt that the altars were intended for sculptures of Joseph and Mary, given the paintings in the Jesuit church, but what occupied them before the arrival of the present sculptures from Tumacácori, reportedly in I 848 , is a mystery. There is one document pointing to a set of previous figures, a report by Cave Johnson Couts, saying that he saw a sculpture of Mary that was miss-

27. For this, see Capistran Hanlon, Acculturation at San Xavier: Changing Boundaries of a Southwest Indian Community, Ph.D. Dissertation, University of Colorado (Ann Arbor, Michigan, University Microfilms, I97I, \#7I-25, 829, pp. 54-7I) and photographs in various publications (e.g. Bernard L. Fontana, Mission San Xavier del Bac, A photographic Essay on the Desert People and Their Church by Helga Teiwes, Tucson, University of Arizona Press, 1973).

28. Robert C. Goss, San Xavier Altarpiece, Tucson, University of Arizona Press, I974, p. 66; Lange and Ahlborn, Mission San Xavier, pp. 136, I38. 
ing an arm two months before the arrival of the Tumacácori sculptures (something that could not be the case of the other two Marian representations in the church). ${ }^{29}$ It seems likely then that there were previous sculptures of Joseph and Mary that needed replacement.

Interesting in respect to these are the bases under the present figures. The base under Joseph is painted in a style seen elsewhere in the church, and there is no reason to suppose that it is from the Anglo Period. Moreover, outlines on the back of Mary's niche indicate the former presence there of a base of the same shape. This was partially dismantled to accommodate the present figure, seemingly because of the wooden block to which she is attached. The presence of bases from the Hispanic Period probably indicates that there was truly an earlier pair of sculptures, and that they too were too small for the niches they occupied. They must have been of the same relative size as the present sculptures, or perhaps somewhat larger. Without further study of the painting on the remaining base to ascertain when it was made, at this point all that can be concluded is that the change in location of these personages to the transept and the change in material from painted to sculpted forms were intended to highlight the parents of Christ with their own altars and, at the same time, to leave space around the main retable for a series of narrative murals detailing the events of Christ's birth. ${ }^{30}$

29. Cave Johnson Couts, Hepah, California! The Journal of Cave Johnson Couts from Monterrey, Nuevo León, Mexico to Los Angeles, California, during the Years I 848-I849, Henry F. Dobyns (ed.), Tucson, Arizona Pioneers' Historical Society, 1961, pp. 61-62; quoted in Fontana, Biography of a Desert Church, pp. 33-34.

30. The present Joseph and Mary sculptures are not similar in style or technology, but they are the same approximate size. See Nicholas J. Bleser's account of their history in Tumacácori: from Ranchería to National Monument, Tucson, Southwest Parks and Monuments Association, I989, p. 43 (also Griffith, Beliefs and Holy Places, pp. 46-47). Ahlborn (Sculptured Saints, p.I2I) notes that the oral tradition of their arrival at Bac after an Apache attack at Tumacácori is supported to some degree by documentary evidence (for this, see Fontana, Biography of a Desert Church, p. 33). Joseph is made of carved wooden planks, something seen in Tumacácori sculptures that do not otherwise resemble it. The Mary figure is different in this respect, but is technically like the Saint Cayetan figure from Tumacácori: viz. the unusual technique of being permanently dressed in paint-soaked textile clothing (for pictures and further discussion of Mary, Joseph, and other figures from Tumacácori once at Bac, see Ahlborn, Sculptured Saints, pp. 8I, I03, and III-IIS).

Other questions involve the identification of the particular Marian type represented. In 1974 Ahlborn (IO3) identified it as the Immaculate Conception, and in 2004 he and Lange reidentified it as the Virgin of the Annunciation (Mission San Xavier, p. I I9). Since the characteristics of 
Further aspects of the Franciscan program may have corresponded to Jesuit ideas, but the Jesuit predecessors either were painted on the walls, and thus not mentioned in the inventories of portable objects, or were not represented visually in their church, but rather mentioned in sermons or other verbal forms. Specifically, I am thinking about the apostle figures that line the Franciscan nave. Although no such images are described in the Jesuit church, and style dictates that the present figures were made for the Franciscan church, the apostles must have been included in sermons and lessons. Evidence of their significance as models for the native congregation is the composition of an important native organization, the settlement's Feast Committee of twelve members. ${ }^{3 \mathrm{I}}$ There is good reason to suppose that this organization's correspondence with the apostles may date from the Jesuit period. The Jesuits emphasized the link of their mission to the apostles in seventeenth-and eighteenth-century Mexico. ${ }^{32}$ And, Kino himself, the Jesuit who founded the missions in the Pimería Alta, named a line of villages along the Gila River north of Bac for the apostles; the river itself he called the Río Grande de los Apóstoles. ${ }^{33}$

This naming was in anticipation of future missions, and although they were never founded, it indicates Kino's thinking in terms of an arrangement comparable to that of the figures in the Franciscan church. ${ }^{34}$ Thus, it is reasonable to think that the linking of the missionary activities on the northern frontier with the apostles, as evidenced in the sculptures in the Franciscan church,

the Immaculate Conception are absent from the sculpture, in contrast to the figure on the main retable, we should probably think of the transept image as representing Christ's earthly parent, but not the Virgin of the Annunciation, because of the upright stance. The painting of Mary in the Jesuit church is called the Virgin of Refuge in one document. Whatever the Tumacácori Mary was before, she was made to serve another purpose at Bac.

3I. As recognized by Hanlon, Acculturation at San Xavier, pp. 54-66. There are other feast committees of different compositions, but the one with twelve members is the most important.

32. Bargellini, "Jesuit Devotions", pp. 683-684.

33. See the map of these villages in Polzer, Kino. A Legacy, p. 89. Their names are (from west to east): Pedro, Pablo, Matías, Mateo, Tadeo, Simón, Felipe, Bartolomé, Iago (Santiago, James the Great), and Andrés. There are ten names rather than twelve. Seven of these are among the eight legible inscriptions at Bac; James the Minor is at Bac but not among the ten villages.

34. Kino was first and foremost an explorer and cartographer, and it is significant that when he gave a sermon to the inhabitants of Bac, he used a map to point out locations of Christian events (Ernest J. Burrus, Kino and the Cartography of Northwestern New Spain, Tucson, Arizona, Arizona Pioneers' Historical Society, 1965, p. 13). 
probably dates from the Jesuit period. When during this time the notion of the committee's comparability to the Apostles was incorporated into native thought is unknown. There were many gaps in Jesuit ministrations at the site, and much disruption by rebellious native groups, so the committee may have been changed or elaborated upon significantly as late as the building of the Espinosa church.

Among other possible Franciscan visualizations of Jesuit themes are the heads of the first Deacon Martyrs of the early Church, Saints Lawrence and Stephen, in oval frames flanking God above the main retable. ${ }^{35}$ As Lange and Ahlborn note, Lawrence and Stephen are represented with the Apostles, on the lower story of the façade of the great Jesuit church of Saint Francis Xavier at Tepotzotlan, Mexico, a church built at the same time as the Jesuit church at Bac. One might add that on the same façade there was a set of Virgin Martyrs, and that all of these early church figures are found at Bac, but in different locations. ${ }^{36}$ However, as in the case of the Apostle figures, in the Jesuit church these probably were presented in verbal narratives rather than in visual imagery.

Some convergences at Bac were probably a matter of like ideas that both Jesuits and Franciscans subscribed to - for instance, ideas about holy figures like the Virgin of Sorrows and the representatives of the early church; while others - for instance, the retention of the church's Jesuit dedicatory saint - were Jesuit only and, although possibly disagreeable to the Franciscans, they were deemed necessary because they were original to the church and had acquired local significance. In addition, the Franciscans would not have wanted to confuse the natives with ideological distinctions between different parties within the Spanish-Catholic world; nor would they have wanted to reveal conflicts. At Bac there is more evidence than so far revealed elsewhere in New Spain of an actual modification of a Jesuit program by a different order. Because the Franciscans brought the parts of their creation together with nearly invisible seams, it is difficult for us to untangle the threads - to analyze the histories, changes, and intentions behind the parts. This is especially true in places like the façade that show no signs of varied hands and sources. Yet comparisons of the motives on it with other churches and with the interior reveal

35. Lange and Ahlborn, Mission San Xavier, pp. 92-93, II2-I I3, I36.

36. Bargellini maintains that the Jesuits were the innovators of iconographic programs in New Spain, and that other parties adopted their ideas ("Jesuit Devotions", p. 689). 
the political conflicts involved in the change from Jesuits to Franciscans and, possibly, subtle messages addressed by the Franciscans to other non-natives. ${ }^{37}$

\section{The Façade}

We know nothing of the old Jesuit façade, but it would not have been like the Franciscan one, which emphasizes the relationship of that order to the holy figures of Christ and the Virgin as well as the Spanish Crown. The church has a retable-façade between two towers, and in this it resembles the multitude of parish churches that sprang up all over Mexico in the second half of the eighteenth century, except in its broader proportions. At the very top are the remains of a sculpture usually identified as the founder of the Franciscan Order, Saint Francis of Assisi. It now consists of a cone-shaped lower body, covered by "hard plaster" in the last quarter of the twentieth century, but some observers reportedly saw the remains of a Franciscan cord at the waist before it was covered. This is debated by Lange and Ahlborn, who argue for the figure's having been a representation of Saint Francis Xavier, the dedicatory saint. Their questioning of the identity of the figure is legitimate but the problem remains unresolved, due to the present state of the image. ${ }^{38}$ Saint Francis Xavier is the

37. The possibility of messages addressed to different parties is suggested by Clara Bargellini in "At the Center on the Frontier".

38. Newhall (Mission San Xavier del Bac, unnumbered page 37) mentions traces of a cord, the sign of a Franciscan, and Edith Hamlin's drawing inside the front cover illustrates it. Lange and Ahlborn's argument, Mission San Xavier, pp. 72-73, that the figure was Francis Xavier is based on a combination of nineteenth-century photographs and the belief that the dedicatory saint of a church is always on both the façade and the main retable. They see a Jesuit type of garment from the front and from the back a cloak, which they believe to have been worn only by Jesuits. Their evidence is not convincing, and the identity of the figure is still in question. The garment is not distinctively Jesuit, and likewise cloaks could be worn by Franciscans as well as Jesuits, as seen in a painted Francis of Assisi also in the church. On the other hand, no photo shows a rope either. What was mistaken for a rope is probably the diagonal line of folds visible in photos taken before the figure was covered. It is possible, however, that these, being like the folds seen on the sculpture of Francis of Assisi on the interior, point to that saint (illustrations of both interior images of Francis of Assisi are on page 69 in Lange and Ahlborn), and it would be very surprising for Francis Xavier to be located in such close proximity with the Franciscan insignia on the façade. Whoever this figure is, the church was obviously dedicated to both Francises through a mix of imagery. By acknowledging two saints of the same name, the Franciscans added to a local confusion of Francis Xavier with Eusebio Francisco (Francis) 
dedicatory saint, and he is highlighted on the interior main retable. However, the church is Franciscan and Francis of Assisi is also represented by a major sculpture inside, above Christ over the Gospel transept altar. In a Mexican church the dedicatory saint is generally found on both the façade and the main retable; at Bac this may or may not have been the case. Whoever the figure is, the insignia below him is definitely Franciscan. So, although the Franciscans did not change the dedication of the church, they put their insignia in prominent places and their own founder in at least one.

Other than this possible irregularity, the façade is like its Mexican contemporaries in announcing the devotions that were explicated on the interior, those to Christ and the Virgin. ${ }^{39}$ These references are in the form of symbolic reliefs combining their monograms with plant and animal metaphors rather than using figurative sculptures. The exclusion of figurative representations of Christ's death on the façade is understandable. The Franciscans had learned in the sixteenth century that the Crucifixion could be misunderstood by new converts and unconverted natives as a form of justifiable violence..$^{\circ}$ It was safer to represent the ideas symbolically with the monograms of Christ and the Virgin surrounded by grape vines standing for Christ's blood transformed into the wine of the Eucharist. Although the insignia of Christ is very like the emblem of the Jesuit order (IHS above three nails and surmounted by a cross), in a Jesuit composition it would have been alone and centrally located, whereas here it forms a pair with the Virgin's name and together they flank a symbol of the Franciscan Third Order. This latter symbol, the crossed arms of Christ and Francis of Assisi nailed to the crucifix (an image that would be difficult to

Kino, the missionary whose character was of mythic proportions in the Pimería Alta. The Franciscans furthered the confusion and could not control the elaboration of the cult. See Griffith, Beliefs and Holy Places, chapter 3.

39. Norbert Raache, "The Façade and Main Altar of the Church of St. Francis Xavier at Tepotzotlan, Mexico", MA Thesis, New Orleans, Tulane University, 1970; Anderson, Figural Arrangements, pp. 9-I3.

40. This contrast between abstract symbols on the exterior and suffering human figures on the interior recalls central Mexican monasteries of the sixteenth century where the first friars avoided exposing the crucified Christ to the native public (Mildred Monteverde, Sixteenth-century Mexican Atrio Crosses, Ph.D. dissertation, Los Angeles, University of California, I972 [Ann Arbor, Michigan, University Microfilms International]). On the preference for symbolic motives on exterior areas, see also John McAndrew, The Open-Air Churches of Sixteenth-Century Mexico, Atrio, Posas, Open Chapels, and Other Studies, Cambridge, Massachusetts, Harvard University Press, 1965, pp. 247-254. 
read by an uninitiated person), refers to the fact that Francis of Assisi bore the wounds of crucifixion also - uniting him with Christ in a relationship that was much closer than that of any Jesuit to Christ.

Another Franciscan sign that underlines this relationship is the cord belt. Introduced within the frame around the Franciscan symbol, it is repeated in a larger sculpted version running below the cornice of the second story. On the inside a similar sculpted rope forms part of the cornice and encompasses the whole interior, with its ends hanging on either side of the dedicatory figure on the main altar. The cross shape of the church traditionally was meant to embody Christ on the Cross, but the interior rope at Bac emphasizes the building's conflation of the body of Francis of Assisi and that of Christ, just as the symbol on the façade indicates the saint's identification with the holy figure.

On the façade the Franciscans linked themselves to the rulers of Spain as well, through emblems from the imperial coat-of-arms. Relieves of rampant lions stand for the kingdom of Leon and the actual towers of the church may stand for the castles of the kingdom of Castile. ${ }^{{ }^{\mathrm{I}} \mathrm{T}}$ The lions differ from the Spanish coat of arms in holding plants, probably sheaves of wheat representing Christ's body transformed into the Eucharistic wafer, just as the vines refer to His blood. The inclusion of Franciscan symbols on a façade was not unusual in eighteenth-century Mexico, ${ }^{42}$ but royal symbols were, ${ }^{43}$ and the purpose was probably political. They were a reminder that the same Spanish

4I. The "castles" of Castile are rendered as church towers in a central Mexican Techialoyan codex from around 1700 (see Xavier Noguez and Rosaura Hernández Rodríguez, Códice Techialoyan García Granados, Toluca, Gobierno del Estado de México-Secretaría de Finanzas y Planeación/ El Colegio Mexiquense, I992).

42. See, for example, the façades of the Franciscan churches in the Sierra Gorda north of Mexico City (Monique Gustin, El barroco de la Sierra Gorda: Misiones franciscanas en el Estado de Querétaro, Siglo XVIII, Mexico City, Instituto Nacional de Antropología e Historia, 1969; Jaime Ortiz Lajous, Querétaro, Tesoros de la Sierra Gorda, Mexico City, Gobierno del Estado de Querétaro and Mosaico Mexicano, 1994). The resemblance between these church façades and that at Bac has been noted by Fontana ("Who Were the Decorators?", p. 376). They too have reliefs of plant forms all over the surfaces and feature the Franciscan symbols of crossed arms and ropes.

43. Rather, these recall sixteenth-century Central Mexican monasteries, where they were displayed on both exteriors and interiors. At Huejotzingo royal patronage is alluded to the chain of the Order of the Knights of Santiago. At Calpan there may be a representation of Philip II on the exterior of a posa (a small building in the atrium). See McAndrew, Open-Air Churches, pp. 320-333. 
dynasty that had ousted the Jesuits sponsored the Franciscan take-over. In fact, since the Jesuits had earlier wrested control of religious life in Central Mexico from the Franciscans, this inclusion of royal symbols on the upper façade may be interpreted as a statement of Franciscan triumph addressed to other Europeans.

In contrast to the more abstract treatment of the upper façade, the lower façade was to be understood in human terms, and its message was less political and more comprehensible to the local congregation. Its organization of niches within a grid of estipites and cornices is very like the interior retables, and figural sculptures likewise occupy the niches. These represent the four female martyrs of the early years of the Christian Church, and, since they are not repeated on the inside, they must have served another function in relation to the interior program.

\section{The Present Arrangement of Figural Sculptures}

The church has an elaborate, yet coherent program that involves both sculptures and paintings (fig. 2). ${ }^{44}$ The paintings that are important to the iconographic program are labeled in the diagram, but even painted motifs that are unimportant in this respect may contribute to the understanding of the sculptures; for instance, some indicate the relative date of arrival of images in the church. ${ }^{45}$ The focus in this section being the sculptures, I will mention only the major paintings. The program includes sixteen attached and thirty-four movable sculptures of personages that can be named (the majority of angels and putti are not included as they probably did not have individual names). ${ }^{46}$ The attached images are in their original locations, of course. They include the disputed Francis and four females on the façade, the eight females in niches above the transept altars, plus God the Father and the decapitated heads of

44. For images of the sculptures and their arrangement, I rely on Ahlborn, Sculpted Saints, and for paintings, I rely on Olney, Analysis of the Murals; see also, Lange and Ahlborn, Mission San Xavier.

45. As demonstrated by Olney, Analysis of the Murals, pp. 59-62.

46. The names are given in Ahlborn (Sculpted Saints) and Lange and Ahlborn (Mission San Xavier). Some are from basal inscriptions, some are from attached attributes and clothing, and others are hypothesized tentatively because the attributes are missing or the inscriptions are lacking or difficult to read. 
two male saints in niches above the main retable (those called Stephen and Lawrence). ${ }^{47}$ Among the portable sculptures ten are the holy figures and saints made for placement in large niches above altars, one is the recumbent Francis Xavier figure (reused Christ) placed upon the secondary altar on the Gospel Side, two are the large angels hanging from the piers flanking the chancel, and the remaining twenty-one are apostles and male members of monastic orders, all destined for small niches. These figures are dressed in a variety of clothing types rendered in a variety of techniques, ${ }^{48}$ but, as stated above, their wooden parts were imported from an unknown city further south in Mexico.

The portability of these sculptures does not imply major problems in their arrangement. The present positions of those that were focal points above altars generally make sense, and conform to rules behind comparable programs in Mexico. There is no reason to think that any (except one whose misplacement is obvious) are located in positions different from those intended for them in the original program. The large ones could fit only in the large niches, and their imagery was distinctive enough for them not to be confused. The two processional figures from the Jesuit church, in particular, were regularly removed and returned to their niches, so the congregation would have known well where they belonged. In the case of the Virgin of Sorrows, there are clear thematic links between the sculpture and the crucifixion scene above her. The obvious misplacement is that of Saint Ignatius Loyola, a small figure who seems to have been intended for a large niche, and this misplacement will be dealt with below. However, a few anomalies exist among the figures that were intended for small, flanking niches. First, there are anomalies that indicate that the friardesigners' ideas could not be realized as originally envisioned when the sculptures arrived from Mexico. In these cases, accommodations had to be made at the time of installation. Second, there are anomalies resulting from changes in the arrangement after its installation. When the church was no longer under Franciscan control, documents indicate the removal of figures and their storage by native parishioners; this introduces the possibility that some could have been misplaced upon their return to the niches. ${ }^{49}$ Such accidental changes would have occurred within the series of small apostles and the series of small

47. Lange and Ahlborn, Mission San Xavier, pp. 92-93, II 2-I I3.

48. See Ahlborn, Sculpted Saints.

49. For discussion of changes among the smaller sculptures and other hypothetical rearrangements, see Ahlborn, Sculpted Saints, pp. I8-19; Olney, Analysis of the Murals, pp. 75-78; and Lange and Ahlborn, Mission San Xavier, pp. I36-I37. 
friars, because the members of these groups would seem to be interchangeable. In addition, there were purposeful rearrangements.

First I will describe the layout of images as it is now, and then explain the anomalies and changes that can be detected, ending with the hypothetical program of 1797 . The program starts on the exterior with the four virgin martyrs of the early church. These lack basal inscriptions, but in earlier times had some of the identifying attributes. ${ }^{\circ}$ The program continues in the nave with the apostles, who were also members of the early church. Their representations line the nave and continue to the main retable, where four flank the central figures on two stories. The names of the apostles are still on some bases but are missing from others. There are only slight differences in the forms, colors, and decorative motifs of the costumes of ten of these. The other two, Peter and Paul, are decorated in markedly dark colors to match the Virgin of the Immaculate Conception between them on the upper story of the main retable. The narrative murals in the nave likewise represent important events in the lives of Christ's followers. To the left of the entrance is the Last Supper, where Christ shared the Passover meal with his disciples and instituted the Eucharist, and to the right is Pentecost, where those disciples that remained after Christ's death and Judas's treachery received the Holy Spirit that made them the first missionaries. Although the names and numbers of apostles vary historically and are a matter of dispute, at Bac the importance of the number twelve seems to have been maintained. The paintings and the sculptures represent Christ's followers at three different times, those at the last Supper, those at Pentecost, and those who became missionaries later. The sculptures are the later missionaries, including Matthias who replaced Judas at Pentecost and Paul who joined later. ${ }^{5 I}$

50. Unfortunately, the female sculptures in the church lack labels, in contrast to the small male sculptures, whose names were written on the bases at the church. Two on the façade are easy to identify as Cecilia and Lucy from attributes they carry (Ahlborn, Sculpted Saints, pp. 42-43). Recently, Lange and Ahlborn (Mission San Xavier, Plate I, pp. 27, 37-38) identified the two questionable figures as Agnes and Agatha, making the group the Four Great Virgins of the Latin Church, which is plausible.

5I. The sculptures are the only ones with names. Just one still holds his distinctive attribute (Peter holds a key), however, but many still have legible basal inscriptions. Ahlborn, Sculpted Saints, reads them as: Saints Peter, Paul, Matthias, Matthew, Thaddeus, James the Great, Andrew, and James the Minor. He identified the three that are totally effaced as Barnabas, Philip, and Bartholomew, and a fourth that was unclear as Simon or John. Since Philip and Bartholomew are among the Indian villages named by Kino on the Río de los Apóstoles, these two identifications seem acceptable. Lange and Ahlborn (Mission San Xavier, p. I I I) reread Ahlborn's Simon/John 
Crossing the nave is the transept with its secondary and tertiary altars. At the end of the Gospel transept arm the two figures in the large niches over the secondary altar are Christ as Man of Sorrows (fig. 5) and above him Francis of Assisi (fig. 6). On the altar is the bier holding the reclining body of Francis Xavier. Flanking Christ and Francis are four male Franciscans. As in the case of the apostles, the names or fragments of names remain on most bases. Those presently in the Gospel arm are: Saints Peter Regalatus and Peter of Alcantara above, and a figure with an illegible inscription and Saint Bonaventure below. Over the tertiary altar next to the chancel are two large niches holding, respectively, Saint Joseph below and Saint Dominic above (fig. 7). Both are relatively small figures of the same approximate size as the small Franciscans and apostles. Joseph is easily recognized from his pairing with the Virgin, his flowering rod (a replacement for an earlier one), and the peg on his arm presumably for the Christ Child. The name on Dominic's base is clear ([St]o Domingo). Both are too small for their niches, so Joseph is on a pedestal and Dominic is on a stack of blocks. ${ }^{52} \mathrm{On}$ the third story above the retable bays are four female nun-saints, who are identifiable from their robes as being from several different religious orders (fig. 8). These do not have inscribed names. ${ }^{53}$

In addition to decorative motives, there are paintings depicting angels holding a rope and chain, flanking Christ, and angels flanking Joseph holding a grape vine and a fish. Assuming that these four angels form a set, the symbols they hold probably identify them as archangels and/or refer to Christ and Joseph in some way. ${ }^{54}$

as Simon, and changed his Barnabas to John (pp. 86-87), a decision probably based on the importance of John and his presence in paintings at the church. The sculptures may not be arranged correctly at present, except for Peter and Paul who belong in the main retable.

52. Seen in a photograph by Helga Teiwes (Ahlborn, Sculpted Saints, p. 74).

53. Ahlborn, Sculpted Saints, pp. 64-69, identified them as Saints Gertrude the Great, Theresa of Avila, Scholastica (?), and Collette. Lange and Ahlborn (Mission San Xavier, pp. I07-8) reidentified Scholastica as Rita of Cascia and Collette as Clare of Assisi.

54. The relationship of the rope and chain to the archangels is unclear. They are seen also at the Franciscan friary of Huejotzingo in Puebla, and both appear earlier at the Franciscan establishment of San Juan de los Reyes in Toledo, Spain. In both cases they have iconographic messages that do not relate to the archangels. At San Juan the rope is used as architectural decoration referring to the Franciscans, and the chains are the actual restraints from which Christian captives of the Moors were freed after the Christian conquest of La Ronda. They probably signified more generally freedom from infidelity or paganism. Ropes and different types of chains carved 


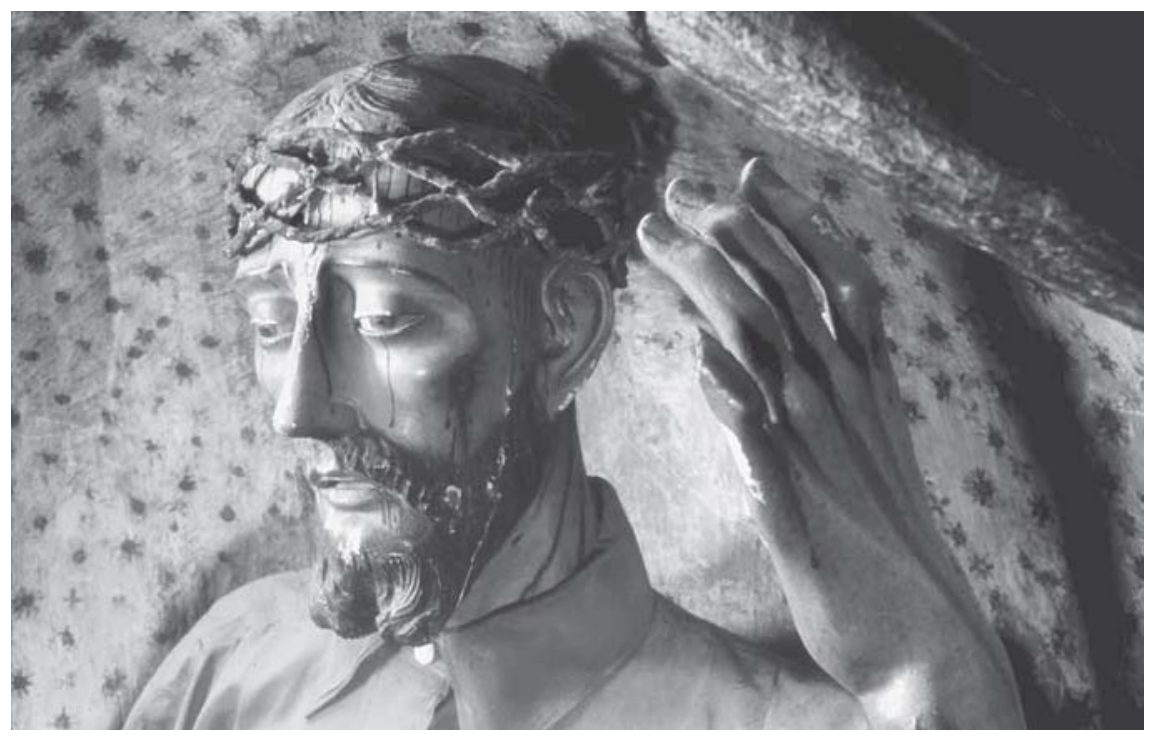

5. Sculpture of Christ as Man of Sorrows (close-up of face), wooden processional sculpture dressed in real clothing, body carved and painted in Mexico for the Franciscan church. The photograph, which was shot prior to recent restoration of the figure, reveals damage to the facial painting. Photograph by Helga Teiwes, courtesy of the photographer.

Finally, there are two framed mural paintings, one on top of the other on the south wall of this transept arm. The lower one is a monumental statue painting of the Virgin of the Pillar, who holds the Christ Child. A pilgrim with the shell of Saint James the Great on his shoulder kneels as a supplicant below, and beside him a text reads: "Rezando Vn. AVE Maria Siempre que diere El Relox delante de Qualquier Imagen de n-ra Señora del pilar ganan ıoo dias de Indulgencias" ("Saying an Ave Maria whenever the clock dictates before an image of Our Lady of the Pillar earns Ioo days of indulgences"). The upper painting is an image of the Christ Child and Mary, perhaps the Presentation in the Temple or the Circumcision. The focus on Christ in this upper painting is appropriate because he is the main subject of the Gospel arm.

as moldings at Huejotzingo most likely constitute specific iconographic references with the same general connotations (see McAndrew, Open-Air Churchess, pp. 320-323, 328). 


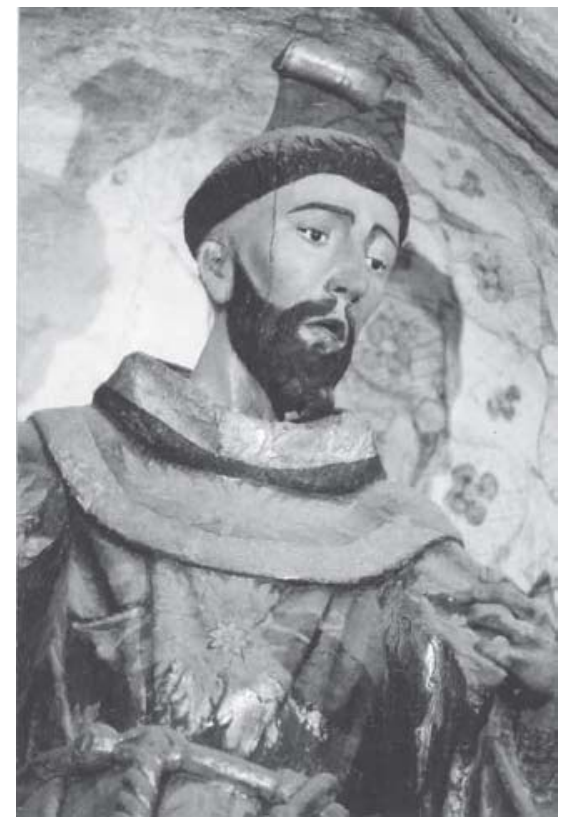

6. Sculpture of Saint Francis of Assisi (close-up of face), Founder of the Franciscan Order, wood, with gilded and painted robes (estofado technique); carved and painted in Mexico for the Franciscan church. Photograph by the author 2005 .

On the opposite side of the church, directly over the altar at the end of the Epistle arm is the Virgin of Sorrows sculpture from the Jesuit church, standing below a crucifix set within a cross-shaped depression in the wall. Originally a sculpture of Christ was on the wooden cross still in the depression, but only one arm has survived (it is now in the church museum). 55 Flanking the cross are paintings of Saint John and the Virgin of Sorrows with seven daggers focused on her heart area. The side bay niches of the Epistle retable contain four more male Franciscans, flanking the painted Virgin and John above and the sculpted Virgin of Sorrows below. Names on the bases indicate that they are Saints Bernardino of Feltre, Fidelis of Sigmaringen, James of Alcalá, and Anthony of Padua. ${ }^{56}$

In the large niche over the tertiary altar, the Tumacácori image of Mary (fig. 9) stands on a rough block of wood which tops the remains of the lower part of the pedestal that once stood there. This image forms a pair with Joseph in the Gospel arm. Above her is a fifth male Franciscan, Benedict the Moor of

55. Ahlborn, Sculpted Saints, pp. гоo-гог.

56. Ibidem, pp. 98, 99, 102, 104, 106. 
7. Small figures in large niches over tertiary altar on Gospel Side: Saint Joseph, father of Christ, below, and Saint Dominic, founder of Dominican Order, above.

Carved and painted in Mexico, the original destination of the Joseph sculpture on the northern frontier is unknown, but it was located reportedly in the church at the mission of Tumacácori (Arizona) before being transferred to Bac in 1848 . Photograph by the author 2005 .

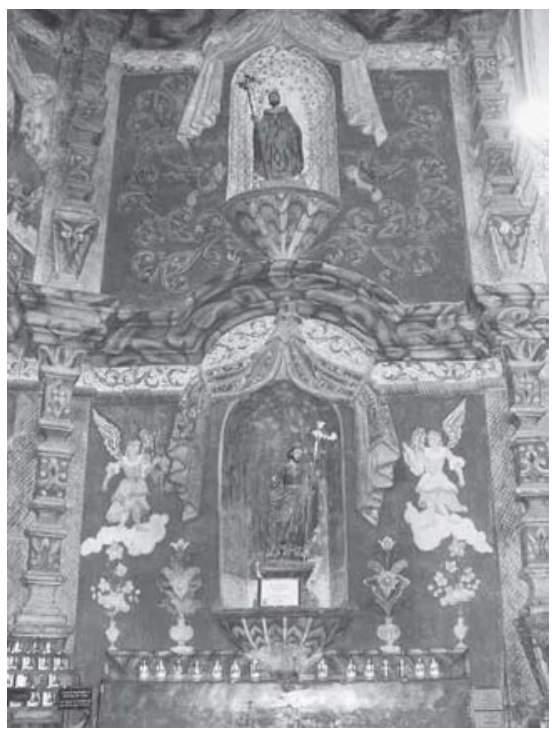

Palermo, who was moved there in recent years, ${ }^{57}$ and beside her, in a niche on the pier where the transept meets the chancel, is Ignatius Loyola, ${ }^{58}$ who, like Saint Dominic, is the same size as the small Franciscans and apostles. Interestingly, the large niches above the transept altars containing sculptures of the Virgin lack the flanking paintings of adult angels found on the Gospel Side. Rather, the Tumacácori Mary has abstract interlaces, while the Virgin of Sorrows has groups of putti (vaguely visible are vessel-like objects in the hands of two of these, which are probably thuribles for incense). Above the retable bays the four female saints are all identifiable as Franciscan nuns by their robes. ${ }^{59}$

57. Labeled "S B... de Filadel....." Ahlborn, Sculpted Saints, pp. 98-99, notes that Philadelphia is an alternate name for Palermo. This figure was once in the niche to the right of its present location, and Benardino of Feltre was in this niche. They were switched in 1968. The word saint is used here and in other publications loosely to designate all the figures in Bac, and this is justifiable as they are all labeled as saints in their inscriptions. However, neither this friar nor Bernardino was a saint in 1797 . Benedict became a saint in 1807; and Bernardino, although beatified, never achieved sainthood (see their biographies in Lange and Ahlborn, Mission San Xavier, pp. 48-49; and John J. Delaney, Dictionary of Saints, second edition, 2003, New York, Doubleday, pp. 88, 93, $605)$. Despite this, in addition to the inscription that labels him as a saint, Benedict has a halo.

58. Ahlborn, Sculpted Saints, pp. 59-6I.

59. Ibidem, pp. 95-97, Ahlborn identified them as Saints Agnes of Prague (?), Elizabeth of Portugal, Clare of Assisi (?), and Elizabeth of Hungary. Lange and Ahlborn, Mission San Xavier, pp. 37-38, 55, reidentified the first as Collette and the third as Agnes of Assisi. 


\section{EMILY UMBERGER}

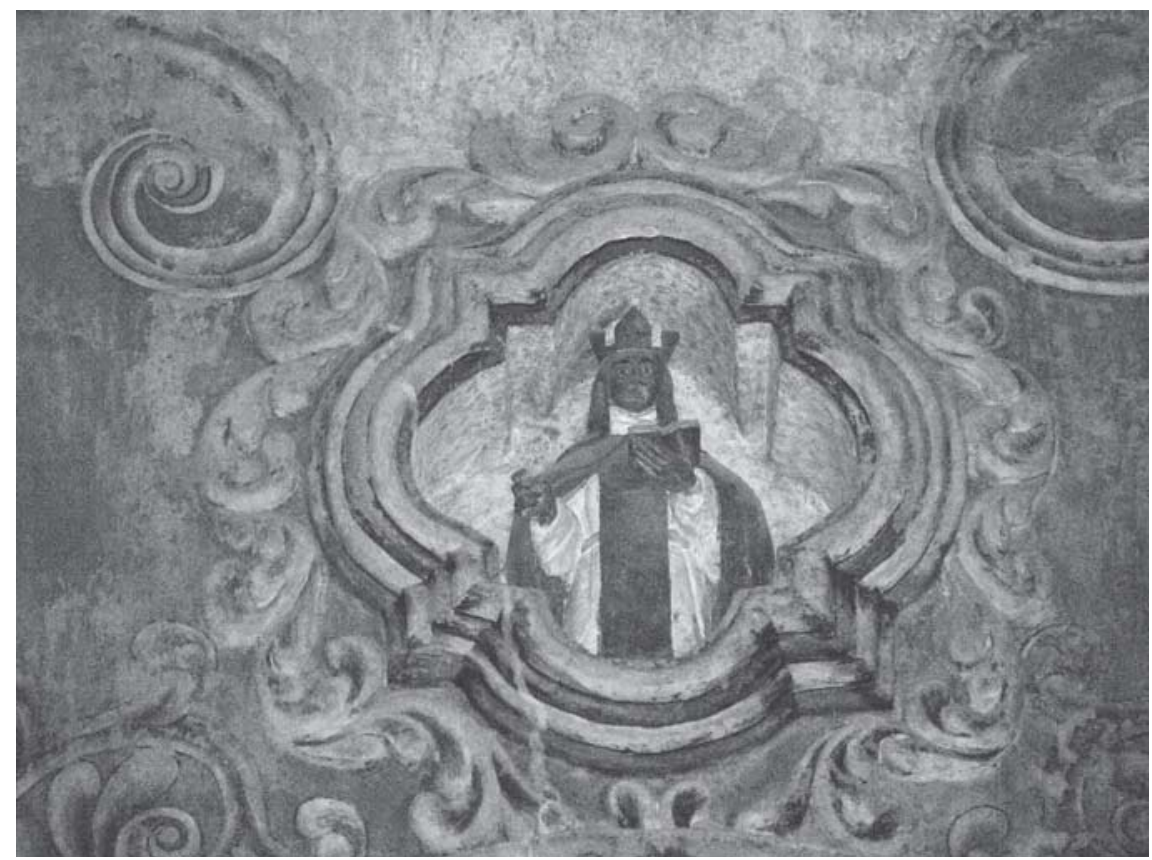

8. Saint Theresa of Avila, one of eight female saints from monastic orders located in frames above the Gospel and Epistle Transept retables. Modeled in plaster, possibly over brick armatures, these were made in situ at the church. The faces and hands of this and the three others on the Gospel (West) Side were darkened with brown paint sometime after their installation. Photograph by the author 2005 .

On the south wall is a monumental painting representing the Virgin of the Rosary or the Virgin of Aranzazu, a specifically Basque devotion (fig. Io). ${ }^{60}$ Like the Virgin of the Pillar that balances it in the Gospel arm, it is a statue painting of a Marian icon with the Christ Child. Although it lacks both the praying figure and writing below, the rosary indicates the words that were to be used. Above is a painting of the Child Mary and Her parents, in keeping with the general dedication of this arm to the Virgin. The book being read by

6o. This identification is relatively recent. The Virgin of Aranzazu, which appeared to a Basque shepherd in 1480 , was patronized by the Franciscans (Lange and Ahlborn, Mission San Xavier, pp. I I9-I 20, following a study by Donald T. Garate [“Arizona, The Basque Connection”, unpublished article, Arizona, Tumacácori, Tumacácori National Historical Park]). 


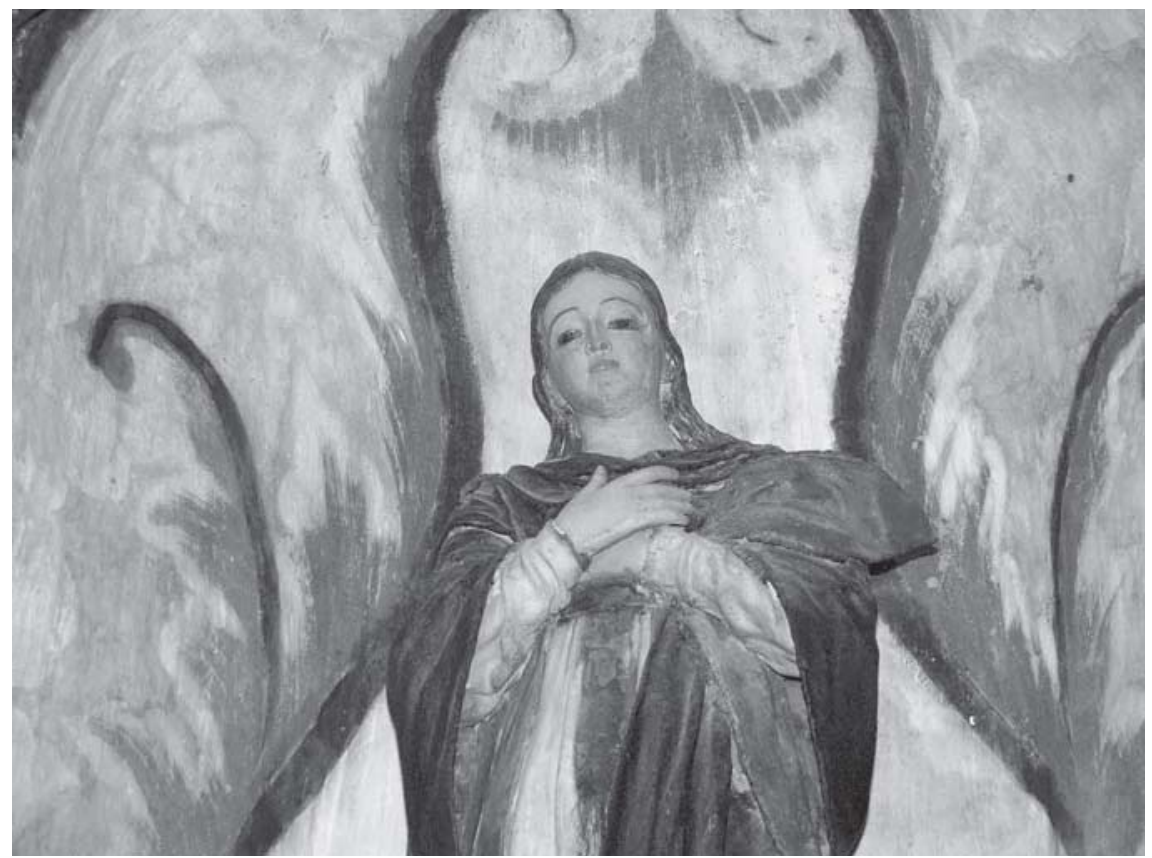

9. Sculpture of Mary (close-up of upper body) above tertiary altar on Epistle Side, date unknown. This image of Mary, which represents Christ's mother, is made of wood clothed in paint-stiffened garments. It was transferred to the Franciscan church at Bac from the church at Tumacácori in I 848 with the Saint Joseph sculpture in figure 7. Photograph by the author 2005 .

the Virgin refers to her learning. Both statue paintings represent the Virgin and Child without emphasizing one personage over the other, despite the dedication of one transept arm to Christ and the other to the Virgin. How they relate more specifically to the other events of the transept is also unknown. One can imagine that they were the objects of petitions from the native congregation, just as the sculptures were.

Between the transept arms are the chancel and its retable, the focus of the whole church. In the center is the figure of the living Saint Francis Xavier, the Jesuit sculpture, placed above the altar and tabernacle. Above him are the sculptures of the Immaculate Conception and the attached figure of God at the top. Flanking the center bay are the four remaining apostles, as stated above, and flanking God are two adolescent angels and the niches with the heads of the two martyrs. On the walls on either side of the retable are narrative 


\section{8}

EMILY UMBERGER

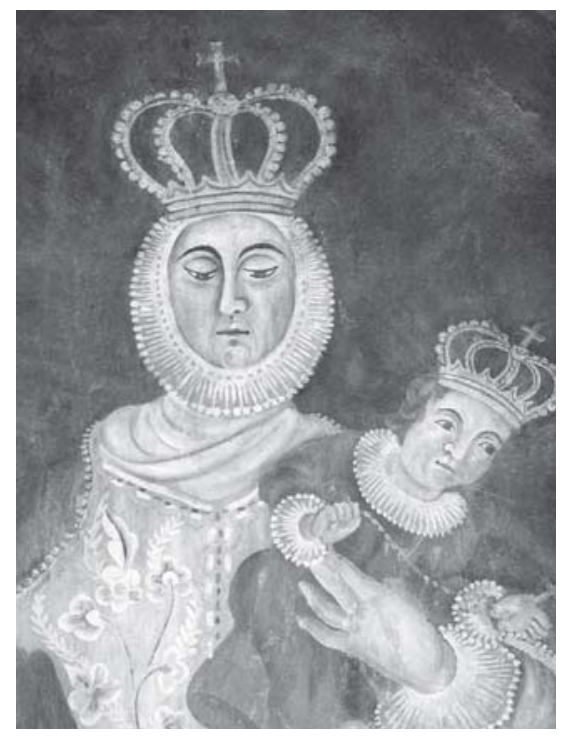

Io. Detail of large devotional fresco painting of the Virgin and Child, identified as either the Virgin of the Rosary or the Virgin of Aranzazu, on the south wall of the Epistle transept arm. This close-up may indicate that the same painter did both the fine decorative painting and the figure painting, the latter an art in which he was not trained.

Photograph by the author 2005 .

paintings, representing the Annunciation and the Adoration of the Shepherds on the Gospel Side and the Visitation and the Adoration of the Kings on the Epistle Side. The nearness of these four scenes to the main altar is logical as they document the events surrounding Christ's birth, His Incarnation in human flesh, which is represented symbolically in the Tabernacle.

Finally, flanking the chancel area are sculptures of the two large Angels hanging from the piers of the crossing (fig. II). They cannot be identified specifically by attributes, but given their location they might be the Archangels associated with the Virgin, Gabriel and Michael, since she is the focus of the main retable. Gabriel was the angel who announced Christ's conception (and he is represented thus in the Annunciation painting), and Michael is considered to have been the Virgin's protector. The positions of their legs and feet seem to indicate that they were intended to stand on clouds or perhaps on the devil in the case of Michael, just as the positions of their hands indicate that they probably once held banners. ${ }^{6 \mathrm{I}}$ They may have served the same function as the smaller two-dimensional angels holding emblems beside the niches with Christ and Joseph in the Gospel arm. 
I I. One of two large angels hanging from the piers flanking the chancel; wooden body dressed in paint-stiffened clothing. The two sculptures must have been in the

Franciscan church before the paintings; the small angels in Figure 7 were modeled after them, as observed by Olney. Whether they were made for the church is unknown.

Above the niche with the apostle to the lower left of the angel the remains of painted plants are showing through the blue surface. Photograph by the author 2005 .

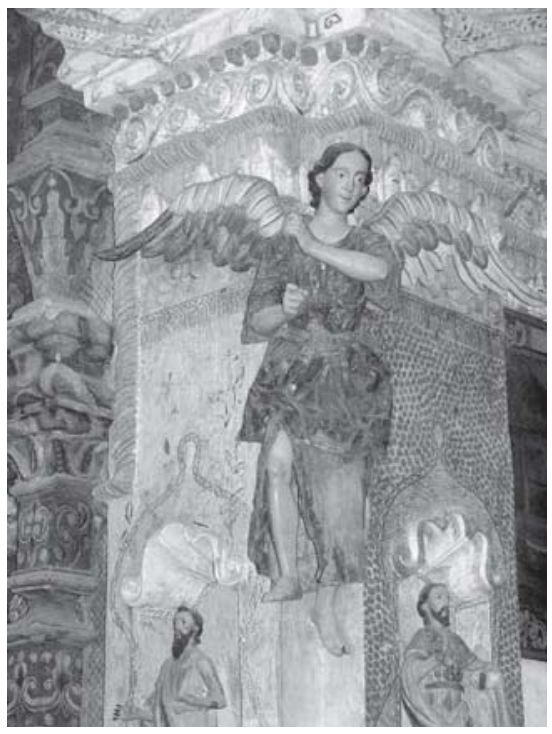

The large figures above the five altars at the north end of the church, just described, dominate the organization of the whole, but there are actually several overlapping organizational structures that work together. Among humans there is a type of chronological ordering from early to late times, going from the early church on the south end — the female martyrs on the façade and the apostles in the nave - to the late church in the transept and chancel — the later friars who are mostly Franciscans. Among the large images in the northern area, the two saints named Francis mix with members of the holy family - Christ, Joseph, and the Virgin. The nave being dedicated to the apostles, the transept arms are dedicated to the suffering of Christ and the Virgin, which the modern saintly descendants of the apostles share. The chancel and its main retable focus on the rewards of suffering: salvation and eternity, through the doctrine of Christ's Incarnation. All altars are activated in the present during different seasons in the church calendar; Mary's altar, for instance, has a small nativity on it at Christmas. ${ }^{62}$ This was probably true in the past, too.

Within the northern areas of the church the chronological consideration that dominated the ordering of human saints breaks down with the juxtaposition of the early modern humans with the holy figures whose historical

62. Hanlon, Acculturation at San Xavier, p. 62. 
lives were contemporary with the figures of the early church. Further, in this northern part, painted scenes are arranged together in areas around sculptures according to theme rather than chronology, and there is even a reverse chronological order from north to south, from the chancel back to the front of the church. ${ }^{63}$ The events of Christ's birth are around the main altar at the northern end of the church, while events that were historically later are located to the south-Christ's death and the institution of the apostles in the transept arms and nave, respectively. But the chancel conflates Christ's historical birth with the timeless events represented by the tabernacle with the Monstrance on it, the living Francis Xavier, the Immaculate Conception, and Saints Peter and Paul, the founders of the Catholic Church.

As Ahlborn states, the overall theme of the church interior, with its focus on apostles and modern saints, is the missionary project to spread the word of the holy events involving Christ and the Virgin. ${ }^{64}$ Additionally, I would emphasize the chronological considerations described above, the timeless aspects of the main retable, and the differentiation between Gospel and Epistle Sides, the latter in keeping with Barbara Anderson's analysis of European treatises and ensembles in Mexican churches. ${ }^{65}$ At Bac the Gospel Side clearly takes precedence over the Epistle Side according to various considerations: especially relative chronology and gender precedence. ${ }^{66}$ The element of time

63. This is implied in Olney's Analysis of the Murals, chapter 6.

64. Ahlborn, Sculpted Saints, pp. 25-26.

65. Anderson, Figural Arrangements. Important precedents to her study include: Francisco de la Maza, Los retablos dorados de Nueva España, Mexico City, El Hijo Pródigo (Enciclopedia Mexicana de Arte 9), I950, and "Simbolismo del Retablo de Huejotzingo", Artes de México, Mexico City, 5 (1959), pp. 26-27; Constantino Reyes Valerio, Tepalcingo, Mexico City, Instituto Nacional de Antropología e Historia, 1960, and Trilogía barroca, Mexico City, Instituto Nacional de Antropología e Historia, I960; Gustin, El barroco en la Sierra Gorda, I969; Norbert Raacke, "Tepotzotlan: Retablo Façade and Retablos", Boletín del Centro de Investigaciones Históricas y Estéticas IV, I973, pp. I I4-I25; Elisa Vargaslugo, La iglesia de Santa Prisca de Taxco, second edition, Mexico City, Universidad Nacional Autónoma de México-Instituto de Investigaciones Estéticas, I982; and María del Consuelo Maquívar, Los retablos de Tepotzotlán, Mexico City, Instituto Nacional de Antropología e Historia, 1976.

66. Anderson, Figural Arrangements. The element of time, which is seen at Bac, is evident also in the arrangement of the paintings in the Church of the Hospital of the Brotherhood of Charity in Seville (Jonathan Brown, "Hieroglyphs of Death and Salvation: The Decoration of the Church of the Hermandad de la Caridad, Seville", in Images and Ideas in Seventeenth-Century Spanish Painting, Princeton University Press, pp. I28-I 46. 
is expressed in the sequence of earlier Gospel Side events and later Epistle Side events within matched pairs of paintings and major sculptures. In addition, precedence of male over female seems to rule in the dedication of the Gospel transept altars to Christ and Joseph and the Epistle transept altars to two different Marian types.

There seem also to be significant relationships among the major figures on opposite sides of the nave. In addition to the pairing of Joseph and Mary on the tertiary altars - where gender rather than time (and importance) dictates Joseph's location on the Gospel Side ${ }^{67}$ - there are interesting links of different types among the other figures. The altar at the end of the Gospel arm focuses on Christ as Man of Sorrows and Francis of Assisi who is identified with Christ's suffering. ${ }^{68}$ In the Epistle arm, the Virgin of Sorrows and the Crucified Christ figure once above her (now missing) were comparable in their positions to the Christ figure and Francis of Assisi in the Gospel arm. There are complex correspondences between these figures across the transept. Christ and the Virgin are comparable as suffering images at earlier and later points during the Passion, and Christ himself is represented in earlier and later images. At the same time Francis of Assisi bears the wounds of crucifixion and he looks across the space at the Crucified Christ.

These ideas about the pairing of Gospel and Epistle examples seem not to be relevant to the present arrangement of small modern saints and apostles. In fact, even their relationships with the major figures and the paintings near them are unknown. In the small figures, the precedence of male over female does rule, but this is a matter of vertical arrangement rather than transept sides. Males and females are on both Gospel and Epistle retables, but males flank the major images, while the female saints are above the retables. This arrangement is characterized by Lange and Ahlborn as a descending hierarchy, in which the important figures are below and the lesser figures above. At Bac, this is in contrast to the ascending hierarchy of the main retable, where the progress from below to above involves increasing importance from Francis Xavier to the Immaculate Conception to God. ${ }^{69}$

67. Olney, Analysis of the Murals, p. 72.

68. The image of the dead San Francisco Xavier was probably not anticipated in the original church.

69. Lange and Ahlborn, Mission San Xavier, pp. I5-18; also Goss, San Xavier Altarpiece, p. I5. 


\section{Anomalies Involving the Apostle Sculptures}

It is in the arrangement of the small male figures, both apostles and modern friars, that the greatest number of anomalies are evident. Of the twelve apostles, two, Peter and Paul, are matched in the coloring of their clothing to the Virgin of the Immaculate Conception sculpture that they flank, and the other ten are different from these two in their lighter colored robes (fig. I 2).

Of the eleven modern friars, nine are Franciscans (figs. I 3 and I 4 ) and two, Saints Dominic and Ignatius, were founders of the Dominican and Jesuit orders, respectively. The friars differ from the apostles in several ways. Among them, there is more purposeful variation in faces, expressions, hair styles, age, and clothing. In other words, differences are a matter of individual characterizations, which are lacking among the apostles. Despite their differences, all members of the two groups, both apostles and friars, are of the same construction (wood bodies and plaster clothing) and, except for one apostle to be discussed later, they are of the same approximate height (between Io6 and I09 $\mathrm{cm}$ ). The locations of the two groups form consistent patterns: the apostles are in the nave niches and the early modern friars are in the transept niches. Since there are twelve female saints altogether - those above the retables and those on the façade - as well as twelve apostles, it seems (again) that twelve was the operative number in groups of multiple figures, so the question is why there are only eleven modern friars ( $\mathrm{I}$ am guessing that one is missing and that its removal dates from after the church's Franciscan period).

The perception that the number twelve was emphasized, along with the patterned locations of types, is behind the identification of anomalies. One anomaly is the presence of only nine occupied niches in the nave, while the tenth is empty. This niche is behind the pulpit and is presently too shallow to hold a figure, but I believe that in the original program it was like the other nave niches - that it held an apostle - and was altered later, as will be explained below. Another anomaly is the placement of one of the friars, Saint Ignatius, in a nave niche. This sculpture not only interrupts the line of apostles along the nave but also does not balance thematically with the corresponding (apostle) figure on the Gospel Side. Given the principle of balance between sides, which obviously dominated the arrangement of images at the church, this niche had to have been occupied by an apostle too. A final anomaly in this area is the location of a Franciscan above Mary, whereas the image in the comparable niche on the Gospel Side is Saint Dominic, who like Ignatius founded 


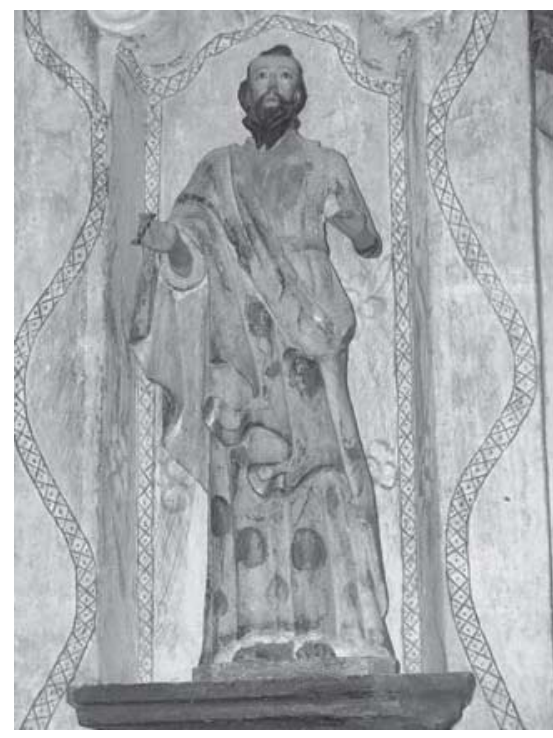

a)

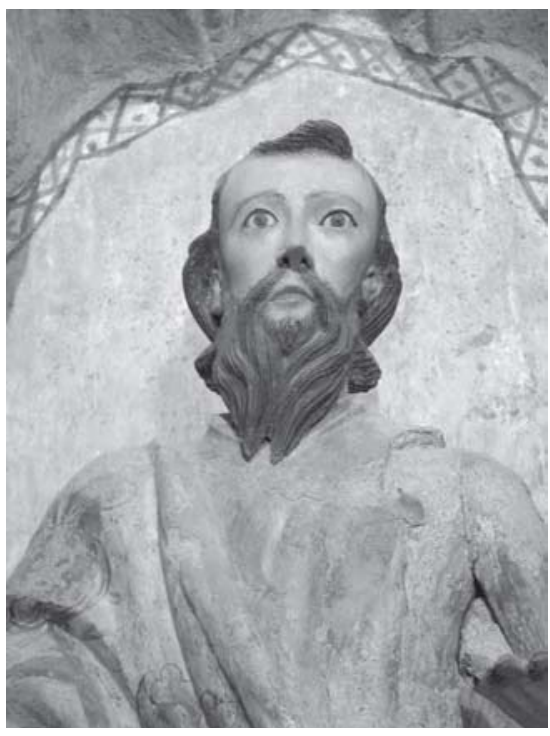

b)

I2. a) One of the ten matched apostle figures made for the Franciscan church, and wearing light-colored clothing. These are now in the niches along the nave and the lower level of the main retable; b) Close-up of face. These wooden figures were carved and painted in Mexico, and plaster clothing was added and painted after their arrival at the Franciscan church. Photographs by the author 2005 .

a monastic order. Logic would place Ignatius in the Epistle niche to balance Dominic in the Gospel niche. ${ }^{70}$

The obvious correction, the removal of the Franciscan saint above Mary and placement of Saint Ignatius in that niche, result in an empty nave niche. If one were to remove one apostle from among the four in the main retable, the only place with extra apostles, to fill it, there would be three apostles left there. I suggest, then, that the third one be removed also to a nave niche, the one behind the pulpit. In other words, since there are twelve apostle figures and ten

70. Ahlborn, Sculpted Saints, p. 19; Lange and Ahlborn, Mission San Xavier, p. I36, in contrast, believe that the figure of Ignatius Loyola was in the main retable, where it was paired with a now missing figure of Saint Francis Borgia. In their reconstruction of the main retable, they are assuming that the whole was quoted from the Jesuit church and they use the main retable at Saint Francis Xavier, Tepotzotlan, as a model. 
niches altogether along the nave, one would be tempted to put apostles in all the nave niches, the one now occupied by Ignatius and the altered, empty one, and leave only two apostles in the main altarpiece niches - Peter and Paul, who obviously belong there. ${ }^{7 \mathrm{I}} \mathrm{I}$ believe this is the solution and will suggest other occupants for the empty niches below them.

Otherwise the arrangement of the apostles is unknown. Perhaps paintings in particular areas will give clues - e.g., the painted images of the pilgrim (identified with Santiago) and Saint John in the Gospel and Epistle arms, respectively - or perhaps there was some sort of internal hierarchy among them, as in the named villages on the Río de los Apóstoles. Or perhaps there was no significant original arrangement of these figures.

\section{The Placement of Two Franciscans in the Main Retable}

The removal of the two apostles from the lower story of the main retable would leave two empty niches, which I suggest were occupied by Franciscans in the original plan of I797. Lange and Ahlborn suggest Jesuit saints in these positions, arguing that the entire retable followed a Jesuit model, but I disagree. ${ }^{72}$ Although the Bac friars were forced to retain Francis Xavier as the dedicatory saint, they would have wanted some of their own brothers in prominent positions on the retable. The most likely candidates for this position are the two figures flanking Christ in the Gospel arm. One is unidentified (fig. I3), his basal inscription being illegible, and the other is labeled as Saint Bonaventure (fig. I4). There are several reasons for arguing for the placement of these two on either side of Francis Xavier. First, they are different from the other small Franciscans in wearing red and white church vestments rather than the brown, rough cloth robes and rope belts of mendicant friars. The vestments - on one a cassock, surplice, and chasuble, and on the other a cassock, surplice, short cape, and biretta - are those that clerics would wear while officiating at the mass in the chancel of a church. Placed in the main retable, these sculptures then would be in the location dictated by their garments and would be comparable in this respect to the image there of Francis

7I. Lange and Ahlborn imply that the pulpit niche originally contained a figure, and they hypothesize a now missing image of Thomas (Mission San Xavier, p. I15).

72. Ibidem, p. 136. 
I3. One of the eleven modern friar saints made for the Franciscan church. This one is presently to the left of the Christ of Sorrows. Like the apostles, the friars were carved of wood and painted in Mexico, and plaster clothing was added and painted at the church. The name on the base has been effaced, but it may have represented Duns Scotus and been originally located on the lower level of the main retable flanking the figure of Saint Francis Xavier and paired with Saint

Bonaventure. Photograph by the author 2005 .

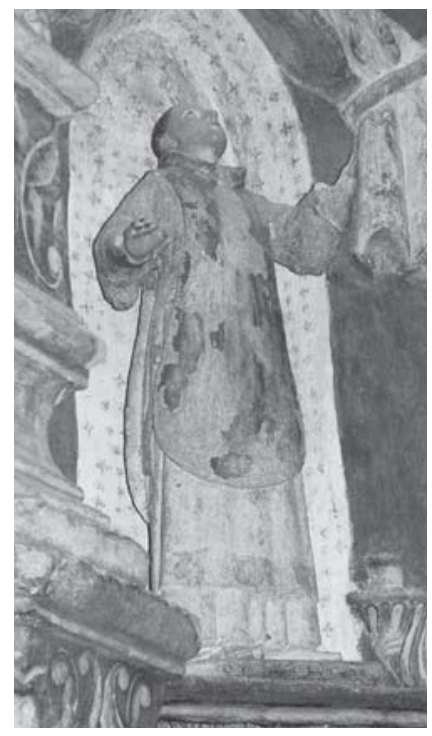

Xavier, who wears a real cloth cassock. The depiction of birettas on top of two of the columns of the retable indicates the same. ${ }^{73}$

Second, there would be significant formal interrelationships among these two and the other figures in the main retable, as well as iconographic relationships with the paintings that flank the retable. The figure without a basal name is the only small figure in the church with head and eyes raised, a position that would make more sense if he were looking up at something, specifically the Immaculate Conception on the second story of the main retable, than it does now in the Gospel retable, where he looks up at nothing. Bonaventure does not look up, but the biretta on his head would echo that of Francis Xavier, and the red and white coloring and painted lace on the clothing of both small Franciscans would complement the larger figure's costume (which is changed from black to red according to season). ${ }^{74}$

My final suggestion is that the unnamed figure might have represented Duns Scotus, the first and best-known theologian to argue for the doctrine

73. As noted by Stacie Widdifield (July, 2005).

74. Colors depend on level in the religious hierarchy and the liturgical theme of a particular day. For religious vestments, see Thesaurus des objets religieux, Paris, Editions du Patrimoine, I999, pp. 305-34I. 
of the Immaculate Conception and the one connected with it by the Franciscans. ${ }^{75}$ In this capacity he was represented previously in a mural at the great sixteenth-century friary at Huejotzingo in Puebla, Mexico, and in a sculpture on the eighteenth-century façade of one of the Franciscan churches in the Sierra Gorda, Querétaro, Mexico. ${ }^{76}$ In both he is one of two figures flanking the Virgin of the Immaculate Conception; in the mural he is with an opponent to the doctrine, the Dominican Thomas Aquinas, and on the façade, he is with another supporter, Sor María de Agreda. His dress, posture, and facial hair vary in different representations, but at Huejotzingo, he wears a biretta, the sign of an officiating cleric. ${ }^{77}$ Although Saint Bonaventure denied the Immaculate Conception, a doctrine that the Franciscans supported as a group by the time Bac was built, he was an important church official, and this fact may be more relevant to his placement in the main retable. Perhaps his specific connection in the program was to the Annunciation, as he is credited with having instituted the ringing of the Angelus bell in honor of that event, and this may indicate that he was on the Gospel Side of the chancel, where that subject is featured in a painting. ${ }^{78}$ Otherwise, since the poses of these two Franciscans are similar although reversed, it is difficult to say which was on the left and which on the right.

If these two Franciscans were moved to the main retable, and if the incorrectly placed Saint Benedict of Palermo (now in the niche that should hold Ignatius) were put in one of the spaces left by these two, or another niche proper

75. Ahlborn, Sculpted Saints, pp. 70-71, 74, 75, and 80, suggested that he might be Saint James of the March, among other possibilities. Lange and Ahlborn, Mission San Xavier, pp. 80-8I, identify him as Saint Ildefonsus of Toledo because of his chasuble, but this seems unlikely because Ildefonsus was not a Franciscan. Like Benedict of Palermo and Bernardino of Feltre, Duns Scotus (ca. I265-I308) was not a saint in I797, and he was not even beatified until I993 (F. L. Cross and E. A. Livingstone (eds.), The Oxford Dictionary of the Christian Church, Oxford/New York, Oxford University Press, 1997, pp. 513-514).

76. For the mural, see McAndrew, Open-Air Churches, p. 34. For the façade sculpture, see Ortiz, Querétaro, p. I 4 (color).

77. Ahlborn, Sculpted Saints, mentions a hole in the head for a halo, and a hole in Bonaventure's head for the biretta. Further examination of both heads should be made to determine if the holes are the same and possibly both for birettas.

78. Bonaventure (I22 I-I274) was a theologian, writer of the official biography of Saint Francis, and church official, who rose to the level of cardinal. He was made a saint in 1482 and named a doctor of the Church in I588. See Cross and Livingstone, Oxford Dictionary, I997, pp. 222-223; J. C. J. Metford, Dictionary of Christian Lore and Legend, London/New York, Thames and Hudson, 1983, p. 52. 
I4. Saint Bonaventure (detail of head), wood with painted plaster clothing. This friar was probably originally located on the lower level of the main retable with the figure identified here as Duns Scotus and Saint Francis Xavier. Photograph by the author 2005 .

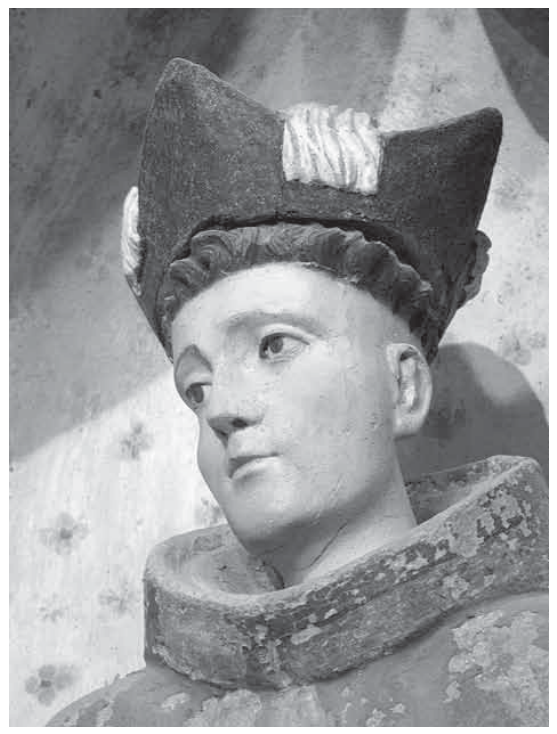

to the Franciscan friars, one transept niche would still lack a figure. It is for this reason that I believe one Franciscan is missing. ${ }^{79} \mathrm{I}$ would guess that, as in the suggested ordering of the main retable, the organization of the Franciscans had significance for the friar-planners; they were meant to relate to each other, the painted decorations, the figures they flank, and the females in niches above them. However, the arrangement probably lacked the same type of interaction across the church that was suggested in the case of the major sculptures. Local relationships might be hypothesized after further study of poses, gestures, and events of the lives of the personages represented.

In summary, the original program of 1797 probably featured the twelve missionary apostles in a line of ten niches along the nave and in two niches flanking the Virgin of the Immaculate Conception. Images of Joseph and Mary, as parents of Christ, were above the tertiary transept altars and above them were the images of Saints Dominic and Ignatius, the founders of the two other important monastic orders in northern New Spain. The smaller niches around the major figures in the transepts were occupied by Franciscans (one image now missing), and the two Franciscans dressed in priestly robes were

79. Lange and Ahlborn, Mission San Xavier, p. I36, also believe that a figure is missing, but their missing figure is a Jesuit saint, something I regard as unlikely. 
located in the lower-story niches in the main retable, where they flanked the dedicatory saint, also dressed as a priest.

\section{The Enlargement of the Pulpit and Rearrangement of Figures}

If the small monastic and apostle sculptures were moved from their original positions in the program, when did this happen, and who did it? It is logical to think that the changes occurred in tandem with the installation of the present pulpit, and the alteration of the niche behind it. There may have been some sort of pulpit in the area from the beginning; a difference in the carving of the lower and upper parts indicates that they were not made at the same time. If the change was an enlargement, it involved an upward expansion so that the pulpit covered the niche. Visual observation reveals that plastering in the area covered a painted red-and-white hatched frame like those around the other nave niches. This seems to indicate that the niche itself was originally like the others and that it was reshaped (the base and crowning volutes being removed) when the area was replastered. Why a shallow, empty niche was preserved is a mystery. It is now popularly believed to stand for the traitor Judas, an unlikely association in the original conception of the program.

It was probably the need to place the apostle from this niche elsewhere that led to the rearrangement of the other small figures. This occurred sometime before the 1870 s, when the first photographs of the interior reveal the present pulpit and arrangement of Franciscans and apostles ${ }^{80}$ (I am not aware of previous mentions of the pulpit). To determine when these changes were made needs more thorough investigation. However, I would guess that it happened after the church's Hispanic period, when the early representatives of us Catholicism retook the church and restored it. This possibility is supported by documentary mentions of building activities. The first concerns Bishop Lamy's friend Joseph Projectus Machebeuf. Having arrived at the church in I 859 , he reportedly "took steps for the repair and preservation of [...] San Xavier del $\mathrm{Bac}[\ldots]$ and succeeded in putting it in such condition that it could be used

80. These are stereographic photos of the interior, in the Arizona State Museum Photo Collections, University of Arizona (Pix 683-x-3), tentatively dated to I87I or I877 in museum records. 
for services." ${ }^{81}$ In I 863 the Jesuit Carolus Evasius Messea talked of plans "for the restoration of the mission [...]" on his way to take up residence there. ${ }^{82}$ And finally, Jean Baptiste Salpointe, who arrived at the church in I 866 and became Bishop of the area later, made further repairs. ${ }^{83}$ Such non-Franciscans would not have been bothered by the removal of Franciscan figures from the main retable and their replacement by apostles, a group whose original number of twelve probably needed to be maintained. The locating of Ignatius in the empty pier niche may or may not have been connected with the pulpit project. The Jesuits, who returned to the site in I 863 would have been pleased to see their founder in the more visible position where he now resides, and may even have put him there, even though he does not match the other apostles in style. Unfortunately, the niche now holding Ignatius is not visible in the I 870 s photographs, so whether he was moved before that period is not known.

\section{The "Communication Gap"}

Some anomalies being understandable as the result of later rearrangements, the remaining inconsistencies/problems in the program seem to be the result of imperfect communication between one or both of the friars involved and the distant sculptors who made the figures, or even between the two friars, as Llorens arrived at Bac after Velderrain's death. Interestingly, most of the sculptures that suggest this imperfect communication are in their proper iconographic locations (with the obvious exception of the Ignatius figure) - evidence that Llorens knew the general outline of the program. The "communication gap" is indicated first of all by the different size and style of one of the nave apostle figures. This figure has the name of an apostle on the base (S. Math..., presumably San Matheo [Saint Matthew]) and he wears the same type of classical robes as the other apostles, but he is anomalous in that he is larger in size and has markedly different facial features and hair style. His hair and beard are short, whereas the other apostles have long, curling hair and beards, and he is probably about Io $\mathrm{cm}$ taller (as judged by his fit in the niche, not his

8I. W. J. Howlett, Life of the Right Reverend Joseph P. Machebeuf, D.D., Pueblo, Colorado, Franklin Press, I908, p. 25I; quoted by Fontana, Biography of a Desert Church, p. 38.

82. Primary sources quoted by Fontana, ibidem, p. 39.

83. Fontana, Biography of a Desert Church, pp. 40-42. 
stated height in Ahlborn's study). ${ }^{84}$ It would appear from this that only eleven matched apostle sculptures arrived at the church, meaning that the intentions of whoever commissioned the sculptures were not understood at the place of production, and that this larger figure had to be dressed as an apostle to make their number twelve.

The second sign of possible miscommunication is the fact that a number of sculptures, likewise in the correct positions iconographically, are of inappropriately small sizes for the large niches that they occupy. Most noticeable in this second category are the figures above the tertiary altars - Joseph and Mary below and Saints Dominic and Ignatius above. While the present Joseph and Mary figures seem to have been added to the program sometime after I 848 , they were probably preceded by equally small sculptures in the same places, as argued above. The style and technology that Dominic and Ignatius have in common with other sculptures at Bac indicate that they were part of the ensemble installed in the I790s, but they also are too small for their niches. What is to be made of this? In fact, no figures in the church, besides those that were located (correctly) above the other altars, are large enough. Since the small and large niches probably indicate the numbers of small and large sculptures anticipated, one logical conclusion is that whoever placed the order for figures and had the niches made wanted some of the figures to be larger in size. It is also possible that the size difference was not considered to have visual significance, or else one or the other of the two friars changed his mind about niche size after the order was placed. Or this discrepancy resulted from the fact that Velderrain died before the project was completed and Llorens inherited incomplete information about it. At any rate, all four figures above the tertiary altars were made too small for the niches.

Whichever friar received the new images at the church had to solve the problems. The small figures, all being sent without robes and names, had to be dressed, decorated, and labeled at the church, and it was here that he and his installers made the changes dictated by the predetermined program. Whoever dressed them had to choose the appropriate clothing, while considering the hair, age, and expression of each figure sent. They were aware that the men with

84. In Ahlborn's table the height of this sculpture is given as comparable to the other apostles (Ahlborn, Sculpted Saints, p. 36), but the figure appears taller in relation to its niche, so the listed height seems to be an error. I cannot guess the original intention of either friars or makers for the figure. It should have had a matching figure, given the balance of elements on the two sides of the church, but there is nothing else comparable in size and hair style at the church. 
longer hair and beards were apostles, and that those with individualized expressions were modern friars, and they must have been able to distinguish Joseph from these as well as the Virgin. Given that there were only eleven matched apostles, they had to make the "mysterious" larger figure into an apostle and they had to put bases under the four figures that were too small for their niches. Another indication of a mismatch is the depiction of the Franciscan Benedict of Palermo (a Moor with dark skin) as a man of light complexion.

The final problem that could be due either to this communication gap or to changes later in the church's history is represented by the figure of Christ. It is the correct size for its niche, but it is posed to carry a cross and there is no room in the niche for a cross. ${ }^{85}$ In addition, it was made as a procession figure, which would typically be removed from its niche, but easy removal is blocked by the location of the bier in front of it. And although there is evidence of the moving of the bier around in the church, I am not aware that this was ever the case as regards the Christ figure.

These problems of figure sizes, poses, and arrangements are definite facts, while the suggested solutions are tentative. Further investigation may produce alternate scenarios.

\section{Questions of Workshops and Training: The Imported Works ${ }^{86}$}

The main decoration of the church at Bac occurred in the final years of the Spanish Baroque, when the arts of painting and sculpture were linked in many ways. In the Hispanic world it was typical for the production and decoration of sculptures to involve separate steps using multiple artists, who were trained in different skills or the handling of different materials. The sculptures sent to

85. Ahlborn, Sculpted Saints, pp. 76-77.

86. Goss, San Xavier Altarpiece, chapter 3, gives generalities about Mexican workshops and the Bac figures. See also, for instance, Francisco del Barrio Lorenzot, Ordenanzas e Gremios de la Nueva España, Mexico City, Genaro Estrada, I92 I; Manuel Carrera Stampa, Los gremios mexicanos: la organización gremial en Nueva España, I 2 I-I86I, Mexico City, Ediapsa, 1954; Francisco Santiago Cruz, Las artes y los gremios en la Nueva España, Mexico City, Editorial Jus, I96o; Rogelio Ruiz Gomar, "El gremio de escultores y entalladores en la Nueva España”, in Gustavo Curiel (ed.), Imaginería virreinal: memorias de un seminario, Mexico City, Universidad Nacional Autónoma de México-Instituto de Investigaciones Estéticas/ Instituto Nacional de Antropología e Historia, I990; María del Consuelo Maquívar, El imaginero novohispano y su obra, Mexico City, Instituto Nacional de Antropología e Historia, 1995; and other studies in the following note. 
Bac were most likely the results of the collaboration of a sculptor or sculptors and a painter or painters. In the case of the sculptures that were dressed at the church, in addition to the original carver/s and painter/s in Mexico, there may have been as many as two additional artists, the plasterer who clothed them and the painter of the clothing. ${ }^{87}$

In addition to the working of multiple artists on single works, a single artist might practice in what we would consider very different artistic forms. A painter, for instance, might paint on flat as well as sculpted surfaces and with the different types of paints required by different surfaces. All painting at Bac is on plaster, and the same style of flower depiction is apparent in wall painting as on clothing. However, in the case of artists who worked in more than one medium, talent and training might lie in one artistic form but not the other. For instance, an artist might be a great painter of sculptures, but not of human bodies and narrative scenes. This too seems to have been the case of the artist/s who worked at Bac.

Two separate types of problems are posed by the imported objects and by the works produced locally. Nine major sculptures - the two Jesuit sculptures, the two Tumacácori sculptures, the reclining Francis Xavier (reused Christ), the remains of the Crucified Christ (just an arm), the Immaculate Conception, and the two large Angels — cannot be linked to other sculptures in the church. In contrast, commonalities in style indicate that twenty-five others, two major sculptures (the Christ as Man of Sorrows and Francis of Assisi) and the twenty-three small ones that still remain in the church seem to have been made by one workshop of carvers or a group of related workshops. Although the places of origin of none of the figures have been determined, this group provides interesting data about its creators, who were definitely multiple.

Given the variety and circumstances of their clothing, evidences of the carvers in this workshop are seen only in the faces, hands, and feet. The large Christ

87. For general works on Spanish sculptures, see María Elena Gómez Moreno, La policromía en la escultura española, Madrid, Publicaciones de la Escuela de Artes y Oficios Artísticos, I943; Beatrice Gilman Proske, Juan Martinez Montañés: Sevillian Sculptor, New York, Hispanic Society of America, 1967; Juan José Martín González, Escultura barroca en España, 1600-1770, Madrid, Ediciones Cátedra, 1983; and the essays in Suzanne L. Stratton (ed.), Spanish Polychrome Sculpture I 500-I 800 in United States Collections, New York, The Spanish Institute, I993. For Mexico, see Gustavo Curiel (ed.), Imaginería virreinal, I990; Maquívar, El imaginero novohispano; and Alfonso Alfaro and María del Consuelo Maquívar, Corpus aureum, escultura religiosa, Mexico City, Museo Franz Mayer and Artes de México, 1995. 
as Man of Sorrows and Francis of Assisi figures are close enough in style to be from the same workshop, but not close enough to be the creations of one carver. The Christ figure, in turn, displays similarities with the eleven apostle figures that form a stylistically coherent group, but the apostles are not the creations of the same artist, and there is evidence of a variety of hands among them. The other small figures, Saints Dominic and Ignatius and the Franciscans form another group, also apparently by more than one artist. Among these, the small Saint Dominic so closely resembles the large Saint Francis that they must be the creations of the same carver, but not the same artists who created the others. There are also possible connections between the small Benedict of Palermo and the large Immaculate Conception, but this is more tentative - given the distance of both figures from a viewer on the floor - and it needs confirmation from further examination.

So style characteristics in faces seem to indicate a single workshop, but the fact that the majority of figures lacked clothing when sent out may indicate a workshop focused on carving and perhaps the painting of encarnación (flesh) but not estofado (clothing) painting. All the painting or creation of clothing would have been done elsewhere. The Christ, apostles, and small friars were made to be dressed elsewhere, while Saint Francis and the Immaculate Conception (if she was part of the commission) were conceived as dressed but were decorated elsewhere in different styles of estofado. Interestingly, among the apostles Peter and Paul seem to have been painted at the church in the same colors as the Immaculate Conception, and only closer investigation will reveal how close in style their locally-made decorations are to the imported estofado of the larger figure.

It is obvious in the differences in carving that there were a variety of hands involved and varying levels of skill, corresponding to a hierarchy based on both talent and training. The large sculptures of Christ and Saint Francis seem to have been the creations of two artists working in very close styles. Their faces are not in the academic styles of sculptures published in Mexican studies; presumably they were from workshops in less peripheral areas of New Spain. ${ }^{88}$ Yet, they are strongly conceived characterizations, with the face of Christ being a more impressive image. They may be productions of masters (maestros) in the hypothetical workshop. In contrast, the treatment of the eleven matched apostles suggests lesser talents - oficiales and aprendices (craftsmen and ap-

88. This observation was made by Ilona Katzew (August 2003). 
prentices). Some of the faces are clearly derivative in style from the large Christ sculpture, and they are all frozen in expression and lacking individualized characterization. The style of the anomalous twelfth apostle, the one that is larger than the others, indicates a different artist in the same workshop, as he resembles the two large sculptures in other ways (for instance, in the ears).

In contrast to the apostles the set consisting of the nine Franciscans and Ignatius and Dominic is difficult to define, more because of the inaccessibility of the figures, even using a telescopic lens, than of the differences in their characterizations. Close-up photos reveal their creators as being as skilled as the artists of the major figures. The faces are more enlivened and varied than the apostles', and individuals of different ages and temperaments are depicted. Only closer examination of details of ears, hands, hair, painting, and other traits will indicate how many artists were probably involved, and whether the suggested workshop ties are plausible.

Other notable creations are the two large Angels attached to the piers flanking the chancel. Although nothing ties them to the other sculptures, Robert Olney argues for their presence in the church before the decorative wall painting, presumably in the I790s, since they provided models for the position of the legs in many figures, most notably in the two-dimensional painted angels (seen in fig. 7). ${ }^{89}$ But these sculptures seem to have been imported from a source different from the rest of the ensemble.

\section{Artists Working at the Church}

Wherever the wooden sculptures were carved, those that arrived without robes were plastered and painted at Bac. So in both two- and three-dimensional works done at the church the focus was on the arts of shaping and painting plaster. There are a great number of examples of both arts (fig. I 5 ), and there are evidences of different levels of skill as well as evidences of later repainting. The question is: how many artists worked at the church, and when? As in the case of the sculptures, the names of the artists probably cannot be found, but future studies of the visual and material evidence might suggest their numbers, training, and sequence of work, as well as distinguishing between work done at the time of initial decoration of the interior and later changes and repairs.

89. Olney, Analysis of the Murals, $59 \mathrm{ff}$. 
I 5 . Finely shaped plaster textile swag with

fine decorative painting, indicating the presence at the church of an artist or artists trained in the skills of plaster modeling and painting in a Mexican workshop or workshops. Photograph by the author 2005 .

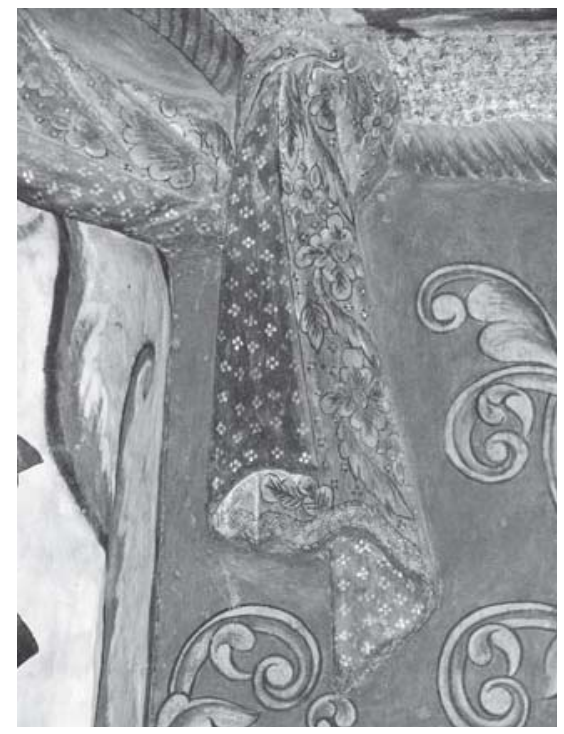

In the Hispanic world an elaborately decorated interior like Bac's would have required many specialists. ${ }^{\circ}$ As explained above, multiple artists might work on a single production and single artists might work on different objects. The number of artists employed and the quality of their work depended on the wealth of the patron, as did the value of the materials. Even at Bac, where faux paintings allude to unattainable materials, a variety of specialized skills were required for its initial decoration. These included: the design of the building and the program of the whole, the translation of the design of the building into a real structure of bricks, the shaping and assembling of brick armatures for the plasterer, the modeling of plaster over the brick forms and wooden sculptures, the decorative painting on plaster walls and clothing, the figurative painting on plaster, and the application and painting of gold and silver leaf on the main retable.

Because of the volume of work at Bac, there had to be multiple artisans involved. However, because of the poverty of the area and the distance from metropolitan Mexico, the myriad tasks had to be accomplished by a small

90. A rare example whose creators are documented was published by René Taylor in Una obra española de yesería: El sagrario de la parroquia de San Mateo de Lucena, Mexico City, Universidad Nacional Autónoma de México, 1978. 
number of trained artisans directing apprentices and amateurs. We know that Indian workers did the manual labor, and it is now fairly certain that the master mason who directed the work was a Spaniard or New Spaniard named Ignacio Gaona; his name is found in both oral accounts and documents. ${ }^{9 \mathrm{I}}$ The number of trained artisans he brought with him is undocumented, but, as in the case of the sculptures created in Mexico, the training, numbers, and relative talents of the creator/s should be visible in the artworks themselves.

Of the two different art forms in which artists worked at the church, I have looked more closely at the painting than the plaster sculpting. Many questions arise. (I) Were the areas where most skill is revealed created by separate artists skilled in the two different specialties, or by a single artist trained in both? (2) Did multiple artists work in either or both arts? (3) If so, are the multiple hands of equal skill, or are there signs of apprentices working in the style of the master/s? (4) Finally, are there signs of later works and multiple campaigns, as separate from restoration and repairs?

There are examples of great skill — evidence of a trained artist or artists — in both decorative painting and in plaster modeling and there are examples of lack of skill in tasks where a trained artist was called for but not present. There are also areas with painted decoration that required no skill, just direction from an artist in charge. These include the faux tile dado and marbling on cornices and other surfaces, as well as the placement of blue spots on the piers. The typical workshop organization argues against an artist having been trained in both sculpting and painting, and, even if this were the case, it would be difficult to find the signs of the same hand in such different forms. It is quite possible that the one who directed the shaping of the brick armatures also executed and/or directed the plasterwork, these both involving three-dimensional skills, but decorative painting is different enough from sculpting to leave open the possibility of separate artists working in these two media. There are also evidences of multiple hands. Hands of equal skill and similar style, for instance, are found in comparisons of the strokes in the separated curvilinear lines used for shadowing in decorative frames and plant forms. Those in the frames in the nave are crisper, and those in the transept are more feathery. ${ }^{92}$ Evidences of different levels of skill are found in the comparison of the faux door in the nave and the

91. See Fontana, "Who Were the Decorators", for current evidence on Gaona and other workers and artisans at the church.

92. I owe these observations to Lise Hawkos. 
seat backs in the choir loft with the much simpler forms of the faux door in the chancel and the faux frames of the squinches under the choir loft.

There are signs in some places of separate campaigns, with earlier campaigns probably creating new forms and later campaigns reconstructing or preserving earlier ones. I have already listed the occasions on which repairs and changes might have been made at the beginning of the Anglo Period. Bernard Fontana and Robert Goss have summarized the information about conservation campaigns in the twentieth century. ${ }^{93}$ In 1906 major renovations in many parts of the structure were directed by Bishop Granjon. Between I 949 and I958, restoration under Celestine Chinn was directed by the architect Eleazar Herreras, who had the artist Henry Milan restore the nave paintings. In I968, the retables were cleaned, and beginning in 1992 paintings all over the church were cleaned and restored (as were the sculptures, judging by the present appearance of some that differ from earlier photographs, notably the figure of Christ).

Campaigns during the earlier Hispanic Period are not documented, but the possibility is suggested by the plant motifs coming through the light blue paint on the left chancel pier. (This blue level, which accompanied the painting of the red-hatched frames of nave niches, was in turn disrupted and covered by plastering after the reshaping of the area behind the pulpit, hypothetically between the I 850 os and the I 870 .) Other evidences of different campaigns may be the notably contrasting styles in different areas, for instance, among the decorations of niches containing sculptures that supposedly were installed at the same time, like the paired images of Mary and Joseph. Joseph's niche background is an all over pattern of small stars against blue, while Mary's features large red and blue curvilinear forms that frame the figure. The same is true of the patterns behind Christ and the Virgin of Sorrows: Christ's niche has an all-over, repeated pattern, while the Virgin's has an aureole of putti heads. A contrast of a different type is in the aesthetic clash between the niche paintings of the main retable - which feature large flowers on a white background - and the uniformly dark and metallic colors of the rest of the parts. Niche decorations like the ones behind the Tumacácori Mary may also be over earlier paintings, and the change would date from when the figure was installed. ${ }^{94}$ Over-painting in the nave is of a different sort; it was

93. Goss, San Xavier Altarpiece, p. Io; Fontana, Biography of a Desert Church, pp. 37-56 passim.

94. This is the implication of Chloe Palmer's study ("Mary of Tumacácori”, student paper in author's possession, 2006). 


\section{I 8}

EMILY UMBERGER

done to repair damage to the narrative paintings and the faux door. There are also signs of over-painting of platforms below niches in the Epistle transept, where it appears that the complex hatched patterns of earlier times were covered by washes in a single color.

The analysis necessary to tackle the problems of earlier and later painting campaigns involves consideration of the fairly subtle evidences of painting styles, layering, and materials. In contrast, one obvious observation can be made about the two-dimensional painted figures: they are by far the weakest productions at the church (fig. I6). Some reveal print sources for iconography, poses, and compositions, and others, according to Olney, reveal the use of some sculptures and plaster relief figures already in the church as models; these models include the large angels flanking the chancel and the plaster putti on the transept walls. ${ }^{95}$ Whatever the sources, in contrast to the fine decorative painting that clearly resulted from metropolitan training, all figural paintings display the artist's (or artists') lack of previous training in the requirements necessary for the creation of individual figures and group compositions. The painted narratives in the nave, whose figures are in the original style, are obviously damaged and over-painted, which might explain some of their dreadfulness, but not the amateurish appearance of the compositions themselves.

The same question arises as in the case of the plastering and decorative painting. Might the skilled decorative painter have painted the figures also? Because of the division of labor in the Spanish world, the idea of a single artist doing two types of painting is more plausible than of a single artist working in both two- and three-dimensional media. Olney has noted places where expertly painted frames, decorated textiles, and implements are in close association or part of figural compositions. Whereas he suggests that two different artists created these images, a single artist is possible, and perhaps probable (see the image of the painted Virgin in fig. Io).

An oral tradition repeated by Fontana states that a lone Mexican artist worked on the interior of the church. ${ }^{96}$ This tradition needs to be considered in any analysis of the church's art. The evidence presented above indicates that this might have been the case of the painting during the initial campaign. If a separate artist did the plastering, this step could have been finished well before

95. Olney, Analysis of the Murals, chapter 4.

96. Fontana, "Who Were the Decorators?", pp. 373. 


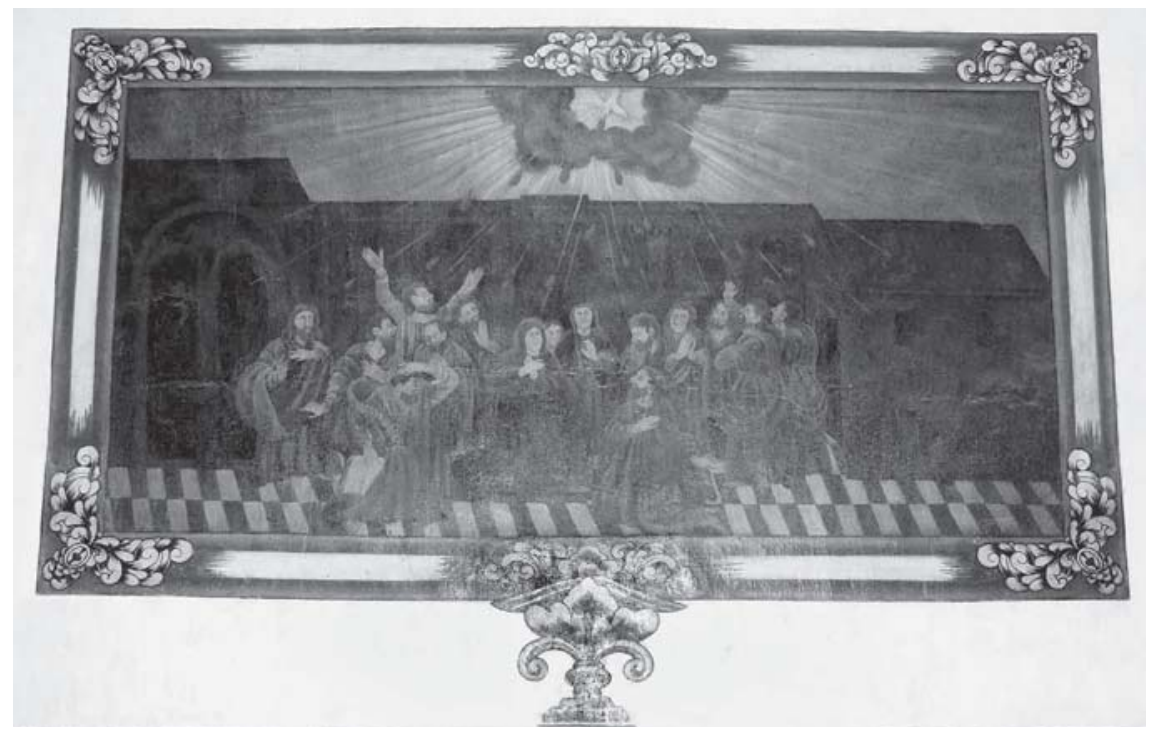

I6. Narrative fresco painting of Pentecost in the nave. This and the other figurative paintings in the church reveal the lack of trained figural painters at the site. Note the contrast between the figural composition and the finely painted decorative frame. Photograph by Helga Teiwes, courtesy of the photographer.

the painting, and the observer who passed on the tradition about the painting did not see this earlier activity. If one artist did both painting tasks, he was trained in a metropolitan workshop in decorative painting but not in figure painting. The minor differences that Olney noted in faces, ${ }^{97}$ plus the lack of the fine decorative details in the painted clothing may indicate assistants directed by the master. If so, we would have to rethink the oral tradition of a single artist.

Another possibility is the involvement of later painter/s who produced new forms in the style of earlier ones. An example might be the motif behind the Tumacácori Mary, which looks very different from comparable niches on the Gospel Side, but imitates the "feathery touch" seen in frames and other parts of the church, as noted above. The painted decoration of the church, in other words, probably involved a history intertwined with that of the sculptures, and extending over the same fifty-year Hispanic period and beyond. 


\section{Local Interpretations and Native Audiences}

In addition to the narrower issues of style and iconography from an European viewpoint reviewed above, there are many questions concerning native contributions that relate the church to broader issues. ${ }^{98}$ It is well-known that Native Americans formed the work crews that built Bac but contributed little of significance to the sculptures and paintings that decorate it, except as possible apprentices as indicated above. Nevertheless, as the audience addressed and as users of the church, they helped shape the program. In other words, although the iconographic layout fits the general outlines manifested by churches in other parts of the Spanish world, and although the creations and creators came from central Mexico, it was designed with the congregation in mind and subsequent congregations altered it. Thus, the questions that Piman specialists might answer are those of reception aesthetics and reception history. How might Pimans have read the church's images? In what ways might the friars have attempted to control their reading, and in what ways were they unable to do so?

That the friars were aware of the native audience might be indicated by the retention of the Jesuit dedicatory saint, an object of native devotion, and of the apostles as models for native behavior. Also notable is the presence of female images. The multiple figures of the Virgin Mary are not unexpected, but what is surprising is the representation of four females on the façade, where usually major saints of a religious order or apostles would be found, and eight more females on the interior. All of these female images were made at the church, a fact that might point to a local agenda addressed by the friar-designers.

Of interest in this respect also are the representations of apostles in both sculptures and paintings in the nave. Although the missionary theme of the church explains these from an European viewpoint, also possible are further meanings for the native congregation. As Capistran Hanlon observed, the pres-

98. For background on Natives and Europeans in the area during the period of European entry, see Daniel S. Matson and Bernard L. Fontana, "Introduction to the Bringas Report: A Microcosm of Indoctrination", in Father Bringas Reports to the King, Matson and Fontana (trans. and eds.), 1977, I-33. Also Spicer, Cycles of Conquest, 1962. Important studies of the Pimas and Papagos are found in William C. Sturtevant (gral. ed.), Handbook of North American Indians, vol. Io: Southwest, Alfonso Ortiz (volume ed.), Washington, D.C., Smithsonian Institution Press, I983, pp. I25-229; various studies by Fontana, Timothy Dunnigan, Donald M. Bahr, Thomas B. Hinton, Frank Russell, and Ruth M. Underhill are listed in the bibliography of this volume. 
ent-day native Feast Committee at the church corresponds in its number of members to the twelve apostles and must be a conscious reference dating from after the arrival of Christianity. ${ }^{99}$ As suggested in an earlier section, the Jesuits either organized or reconfigured this committee, and the Franciscans continued to foster it. So, how would the native congregation have read the paintings of the Last Supper and Pentecost in the nave? Given the committee's job of setting up church feasts, for instance, its members would have identified especially with the Last Supper painting.

Also relevant perhaps is the fact that the apostle sculptures are separated from the female saints, who are on the façade outside the church. The traditional organization of a Piman village emphasized a men's house, where the adult men reached consensus. Male and female activities were separated, so women were not allowed inside this building, but could wait outside for their men. That the Feast Committee was conceived as comparable to the apostle sculptures and that the women of the committee members were comparable to the façade sculptures is implied by a photograph taken by Helga Teiwes, which records the ceremony wherein one committee replaced another at the beginning of a new ceremonial year. ${ }^{100}$ The two groups of twelve men, the old and new committees, are lined up in front of the church façade, facing each other like the apostles inside. In contrast, the women who support the new committee are grouped at the gate of the atrium to the south of the lined up men, just as the females on the façade are outside the church containing the apostles. ${ }^{\text {III }}$

There are many further questions that could be asked about the native congregations. How did they feel about the spatial and temporal arrangement of the program, the sequencing of events along the north-south axis, and the temporal priority of the Gospel over the Epistle Side? If they were conscious that the Gospel was to the west, the sunset side, how did they feel about European

99. Hanlon, Acculturation at San Xavier, p. 6I.

Ioo. In Fontana, Mission San Xavier, unnumbered page 2I after title page, lower photo.

IоI. The small female saints on the interior are also separated from the males, being placed above the transept retables. But although the two groups are separated, obviously it was still important to include the women. Important studies of gender in native North American societies vis-à-vis the Spanish and Christian arrival include Ramón A. Gutiérrez on New Mexico (When Jesus Came, the Corn Mothers Went Away: Marriage, Sexuality, and Power in New Mexico, I500-I846, Stanford University Press, I99I) and Virginia M. Bouvier on California (Women and the Conquest of California, I 542-I840: Codes of Silence, Tucson, University of Arizona Press, 2001). 
ideas that placed later events on the east, the sunrise side? ${ }^{\text {102 }}$ The darkened faces of the women on the west side might indicate that native directional ideas were still active. If so, was there a conflict here? One might also ask how the saints and holy figures were understood. Surely, the native congregations conceived these powerful beings in terms of their own ideas about human repositories of spiritual power. Hanlon supports this notion when he documents the use of native gestures towards the Francis Xavier sculpture and the treatment of household saints that were brought into the church periodically. ${ }^{103}$ Given that saints are also incorporated into modern curing practices, how did native ideas about disease affect their understanding of the Bac saints? ${ }^{\text {I04 }}$ Finally, how did the native congregations perceive the various representations of plants and animals? Those that were indigenous to the area might have been parts of local allegories, and those that were introduced by Europeans might have had significance connected with this origin.

In all these cases, the native congregation would have read the Christian imagery in their own ways, no matter how much the friars tried to guide their interpretations. The specifics of the early period will be especially difficult to recover because so little is known of Piman culture before modern times, but analogical speculations can be attempted. ${ }^{\text {IOS }}$ Franciscan intentions in creating the program and Piman responses are "two sides of the same coin." Church programs like the one at Bac were created for use in teaching the congregation, with the religious in charge connecting parts through verbal narratives. At the

I02. For many evidences of native consciousness of the four directions of space, see Ruth M. Underhill, Donald M. Bahr, B. Lopez, J. Pancho, and D. López, Rainhouse and Ocean: Speeches for the Papago Year, Flagstaff, Museum of Northern Arizona (American Tribal Religions 4), 1979. See also Hanlon (Acculturation at San Xavier, chapter 2) for the directional orientation of structures outside the church for church-related activities.

I03. Hanlon, Acculturation at San Xavier, pp. 60, 7 I.

I04. On curing, see Donald M. Bahr, Juan Gregorio, David I. López, and Albert Álvarez, Piman Shamanism and Staying Sickness (ká:cim múmkidag), Tucson, University of Arizona Press, I974.

105. For studies of native reinterpretations of Christian iconography in central Mexico, see Jeanette Favrot Peterson, The Garden Frescoes of Malinalco: Utopia, Imperial Policy, and Acculturation in Sixteenth-Century Mexico, Austin, University of Texas Press, 1985; James Lockhart, "Some Nahua Concepts in Postconquest Guise", History of European Ideas 6, 1985, pp. 465-482, Oxford/ New York, Pergamon Press; Carol Hamill Callaway, The Church of Nuestra Señora de la Soledad in Oaxaca, Mexico, Ph.D. dissertation, University of Maryland, College Park, 1989, and "PreColumbian and Colonial Mexican Images of the Cross: Christ's Sacrifice and the Fertile Earth", Journal of Latin American Lore, I6:2, I990, pp. 199-231, Los Angeles, University of California, Latin American Center. 
same time that the friar was preaching, the congregation members were connecting the parts according to their cultural traditions as well as ways taught to them by the church. In a church like Bac the clues to connections made by different makers and readers may or may not be present in the material remains, or they may be present in subtle clues that are difficult to read. While the early history of the church is crucial, its post-construction history must also be thoroughly studied. Questions concern changing politics, religious ideas, and preservation, all of which can help expand our notions of the possibilities of reception and reinterpretation during different periods. A primary aspect in all of these periods is the church's geographic location, first on the far northern frontier of the Spanish empire and then on the us side of an international border. ${ }^{106}$ Since its initiation as a place of missionary focus, Bac has been a site of negotiation among many parties, and there are an infinite number of aspects still to be investigated at each point in its history. $\stackrel{5}{5}$

I06. I am following Clara Bargellini in emphasizing geography, a major theme in "At the Center on the Frontier", 2004.

NB: This is a revised and expanded version of a paper delivered at the Eleventh International Congress on the Enlightenment at UCLA, Los Angeles, August 8, 2003. I thank Clara Bargellini for encouraging me to pursue this investigation and for many suggestions. I am grateful to Bernard L. Fontana for emails explaining the present situation of archives and research on the church and providing further bibliographical sources. Special thanks are owed to Stacie Widdifield and Gene Mandish for their hospitality in Tucson and for their help with photography at the church, to Diana Fane and Robert Olney for suggestions, and to Anne Gully for editing. I am indebted also to two students, Chloe Palmer and Casandra Hernandez, who studied sculptures at Bac for term papers in the Spring 2006 semester at ASU. For help at the Arizona State Museum Photo Collections, I thank Susan Luebbermann and Chrystal Carpenter Burke. 